Zabytkoznawstwo i Konserwatorstwo XL, Toruń 2011

Justyna Olszewska-Świetlik, Ewelina Pawlak

\title{
Warsztat malarski cyklu obrazów emporowych z kościoła pod wezwaniem św. Jana w Gdańsku*
}

$\mathrm{O}$ brazy dekorujące w przeszłości emporę w kościele pod wezwaniem św. Jana w Gdańsku są przykładem sztuki związanej z wyznaniem protestanckim. Empora będąca rodzajem galerii lub trybuny służyła w kościołach przede wszystkim do powiększenia powierzchni użytkowej. Wywodzi się prawdopodobnie z Bliskiego Wschodu. Dość często występowała $w$ okresie średniowiecza, jednak jej rozkwit przypada na okres baroku. W wieku XVII stała się typowym elementem wyposażenia zborów ewangelickich ${ }^{1}$. W Gdańsku większość empor powstała w XVII i XVIII stuleciu². Kościół pw. św. Jana Chrzciciela i św. Jana Ewangelisty (jak brzmi jego pełne wezwanie) od 1559 roku do 1945 roku znajdował się we władaniu ewangelików ${ }^{3}$. Na jego pierwszego pastora nominowano w 1559 roku luteranina Jana Husinga ${ }^{4}$. Budowa empory w kościele pw. św. Jana trwała od 1622 do 1666 roku. W latach sześćdziesiątych

* Artykuł powstał w oparciu o pracę magisterską uzupełnioną dodatkowymi badaniami autorek. Por. E. Pawlak, „Wybrane obrazy z cyklu malowideł emporowych z kościoła św. Jana w Gdańsku jako przyczynek do technologii i techniki nowożytnych warsztatów cechowych", pod kierunkiem dr hab. J. Olszewskiej-Świetlik, prof. UMK, Zakład Technologii i Technik Malarskich UMK w Toruniu 2008, mps.

1 Słownik terminologiczny sztuk pięknych, red. S. Kozakiewicz, Warszawa 1976, s. 125-126.

2 K. Cieślak, Sztuka reformacji 1557-1793, w: Aurea Porta Rzeczypospolitej. Sztuka Gdańska od połowy XV do końca XVII. Eseje, t. I, red. T. Grzybkowska, Gdańsk 1997, s. 60.

3 Ks. St. Bogdanowicz, Kościót św. Jana w Gdańsku, Gdańsk 1992, s. 141; Katalog Zabytków Sztuki. Miasto Gdańsk, cz. I: Główne miasto, red. B. Roll, I. Strzelecka, t. VIII, Warszawa 2006, s. 148-159.

4 P. Szczudłowski, Losy poewangelickich obiektów sakralnych na terenie diecezji gdańskiej, Lublin 2001, s. 31. 
XVII wieku powstało dwadzieścia osiem obrazów na płótnie o tematyce zaczerpniętej ze Starego i Nowego Testamentu, które ozdobiły pola balustrady empory (il. 1-2) . Część empory obiegającej transept zdobiona była pięcioma obrazami, w nawie południowej znajdowały się pozostałe dwadzieścia trzy obrazy (il. 3) ${ }^{6}$. Źródłem ikonograficznym tematów biblijnych z empory były grafiki Mateusza Meriana Starszego (1593-1650) z Biblii luterańskiej wydanej w 1630 roku w drukarni Lazarusa Zetznera w Sztrasburgu (il. 4-5) ${ }^{7}$. Pierwszy egzemplarz zawierał sto pięćdziesiąt siedem miedziorytów do Starego i siedemdziesiąt siedem do Nowego Testamentu. Zachowały się również trzy księgi, w których grafiki były ręcznie malowane. Jedna $\mathrm{z}$ nich znajduje się $\mathrm{w}$ Württembergischen Stadtbibliotek w Stuttgarcie. Kolory użyte w ilustracjach są jasne, pastelowe, dlatego nie zakrywają charakterystycznych linii grafik. W związku z szerzeniem się luteranizmu, wielu malarzy czerpało pomysły z Biblii Meriana. Wykorzystywano je szczególnie często w dekoracjach empor, między innymi na terenie Niemiec, czego przykładem mogą być protestanckie kościoły we Frankfurcie nad Menem, Weissensee, SteinbachHallenbergu, Speer oraz w Hospitalkirche w Hof ${ }^{8}$. Na terenie Polski, poza obrazami z kościoła pw. św. Jana w Gdańsku, układy kompozycyjne zaczerpnięte $z$ grafik Meriana występują na przykład w obrazach zdobiących drugą i czwartą emporę kościoła ewangelicko-augsburskiego w Jaworze9.

Obrazy z empory kościoła pw. św. Jana powstały w jednym $\mathrm{z}$ anonimowych warsztatów działających na terenie Gdańska. Domniemano, że twórcą obrazów mógł być Baltzer Muncke, który miał je wykonać w 1664 roku $^{10}$. Według Wielkiej księgi cechu malarzy gdańskich

5 W. Drost, Künstdenkmäler der Stadt Danzig-Sankt Johann, Stuttgart 1957, s. 79. W literaturze znajdujemy również datowanie na rok 1622; Katalog Zabytków Sztuki. Miasto Gdańsk, s. 158.

6 W. Drost, Künstdenkmäler der Stadt Danzig-Sankt Johann, s. 79.

7 Die Merian Bibel, Stuttgart 1980.

8 Neuapostolische Kirche in Deutschland, http://www.nak.de/news.de/ 20030217-134-de.html.

9 http://www.jawor.pl/jawor/index.php?strona=dziall.php\&n=15.

10 W. Drost, Künstdenkmäler der Stadt Danzig-Sankt Johann, s. 79; J. Pałubicki, Malarze gdańscy, t. II, Gdańsk 2009, s. 550-551. 
Christiana Friedricha von Falckenbercka, Baltzer Muncke otrzymał tytuł mistrza 19 października 1644 roku. W krótkim opisie, umieszczonym przy jego nazwisku, wymieniona jest również data śmierci malarza - 1664 rok, dzięki której można wywnioskować, że nie mógł być jedynym autorem badanych obrazów, ponieważ budowę empory ukończono w $1666 \mathrm{roku}^{11}$.

Po drugiej wojnie światowej spośród 28 obrazów z empory zachowało się 26. Zaginęły 2 obrazy: Oczyszczenie warg Izajasza oraz Chrystus błogosławiacy dzieci, 26 pozostałych zdeponowano w Muzeum Narodowym w Gdańsku, gdzie znajdują się do dziśs ${ }^{12}$.

Do kompleksowych badań technologii i techniki malarskiej wytypowano osiem następujących obrazów: Adam i Ewa, Ofiara dziękczynna Noego, Aniołowie u Abrahama, Walka Jakuba $z$ Aniołem (transept), Ozeasz i Gomer z dziećmi, Św. Jan Chrzciciel, Chrystus i uczeni w piśmie, Wskrzeszenie córki Jaira - nawa południowa (il. 3). W obrazach tych nie stwierdzono wcześniejszych ingerencji konserwatorskich (np. dublażu) aniwarstwwtórnych (np.przemalowań), cobyłopodstawowymkryterium wyboru umożliwiającym prawidłowe określenie oryginalnej techniki.

11 C. F. von Falckenberck, Das Grosse Meisterbuch, 1724, Archiwum Państwowe Gdańsk, 300, C/613; J. Pałubicki, Malarze gdańscy, t. II, Gdańsk 2009, s. 551.

12 Adam i Ewa, wym.: 87 x 123 cm, nr inw. MNG/SD/495/M; Ofiara Noego, wym.: 87 x $120 \mathrm{~cm}$, nr inw. MNG/SD/496/M; Aniołowie u Abrahama, wym.: 87 x $120 \mathrm{~cm}, \mathrm{nr}$ inw. MNG/SD/497/M; Ofiarowanie Izaaka, wym.: 87 x 99 cm, nr inw. MNG/SD/498/M; Walka Jakuba, wym.: 87 x 99 cm, nr inw. MNG/SD/499/M; Mojżesz, wym.: 86 x 98 cm, nr inw. MNG/SD/500/M; Jeremiasz, wym.: 81 x 98 cm, nr inw. NNG/SD/501/M; Ezechiel, wym.: 83 x $99 \mathrm{~cm}$, nr inw. MNG/SD/502/M; Daniel, wym.: 87 x $102 \mathrm{~cm}$, nr inw. MNG/ SD/503/M; Ozeasz, wym.: 85 x 97 cm, nr inw. MNG/SD/504/M; Św. Jan Chrzciciel, wym.: 85 x $99 \mathrm{~cm}, \mathrm{nr}$ inw. MNG/SD/505/M, Chrystus w synagodze, wym.: 84 x $96 \mathrm{~cm}$, nr inw. MNG/SD/506/M; Św. Piotr idacy po wodzie, wym.: 86 x 97 cm, nr inw. MNG/SD/507/M; Wskrzeszenie córki Jaira, wym.: 86 x 97 cm, nr inw. MNG/SD/508/M; Przemienienie, wym.: 87 x $97 \mathrm{~cm}, \mathrm{nr}$ inw. MNG/SD/509/M; Powołanie św. Filipa, wym.: 85 x $96 \mathrm{~cm}, \mathrm{nr}$ inw. MNG/SD/511/M; Rozmnożenie chleba, wym.: 86 x 98 cm, nr inw. MNG/SD/510/M; Zesłanie ducha świętego, wym.: 97 x 87 cm, nr inw. MNG/SD/635/M; Chrystus i Tomasz, wym.: 85 x 96 cm, nr inw. MNG/SD/534/M; Uzdrowienie niewidomego, wym.: 85 x $95 \mathrm{~cm}$, nr inw. MNG/SD/533/M; Chrystus nauczajacy, wym.: 85 x 95 cm, nr inw. MNG/SD/529/M; Chrystus i Samarytanka, wym.: 85 x 97 cm, nr inw. MNG/SD/532/M; Nawrócenie św. Pawła, wym.: 85 x $95 \mathrm{~cm}$, nr inw. MNG/SD/531/M; Powołanie św. Mateusza, wym.: 84 x $86 \mathrm{~cm}$, nr inw. MNG/SD/536/M; Salome, wym.: 85 x $98 \mathrm{~cm}$, nr inw. MNG/ SD/530/M; Chrystus w drodze do Emaus, wym.: 85 x 93 cm, nr inw. MNG/SD/535/M. 
Budowę techniczną obrazów oraz identyfikację materiałów malarskich ustalono poprzez zastosowanie wzajemnie się uzupełniających nowoczesnych metod fizycznych, m.in. mikroskopowych, chemicznych i instrumentalnych ${ }^{13}$.

Z badań technologicznych wynika, że podłożem dla wszystkich obrazów było płótno lniane ręcznie tkane o splocie płóciennym.

13 Analizę i fotografię w IR i UV lica obrazów wykonał mgr A. Cupa, interpretację - autorki publikacji w Zakładzie Technologii i Technik Malarskich IZK, UMK w Toruniu. Do badań w podczerwieni zastosowano cyfrowy system do reflektografii w zakresie bliskiej podczerwieni z filtrem $780 \mathrm{~nm}$, w UV lampę typu Emita z filtrem Wooda $365 \mathrm{~nm}$.

Badania lica obrazów w UV służyły przede wszystkim do określenia stanu zachowania obrazów i zidentyfikowania warstw wtórnych, w celu prawidłowego wytypowania miejsc pobrania próbek. $Z$ tego względu nie zamieszczono w publikacji tego rodzaju fotografii. Próbki zatopiono w żywicy „Duracryl Plus” prod. Spofa, Dental - Czechy, wyszlifowano przy użyciu papierów ściernych o granulacji od 300 do 2000. Obserwację wykonano przy zastosowaniu mikroskopu Optiphot 2, powiększenie 40 i 100 razy, w Zakładzie Technologii i Technik Malarskich IZK, UMK w Toruniu.

Fotografię przekrojów fluorescencji w ultrafiolecie wykonała dr Zuzanna Rozłucka w Zakładzie Konserwacji Malarstwa i Rzeźby Polichromowanej IZK, UMK w Toruniu. Używano mikroskopu fluorescencyjnego Nikon Eclipse E 600, powiększenie 100 i 200 razy, zintegrowanym z lampą rtęciową Nikon Super HB 1010AF i standartowym blokiem filtrów UV 2A: EX 330-380 nm, DM $400 \mathrm{~nm}$, BA $420 \mathrm{~nm}$. Na temat zastosowanej metody i aparatury patrz: Z. Rozłucka, M. Roznerska, J. Arszyńska, Mikroskopia fluorescencyjna. Zastosowanie w badaniu budowy i procesów konserwacji malarstwa sztalugowego, Toruń 2000.

Badania mikrochemiczne wykonano na przekrojach poprzecznych i wypreparowanych warstwach. Przeprowadzono analizy w roztworze: reakcje mikrokrystaloskopowe, kroplowe, analizy suche, prażenie, barwienie płomienia perły boraksowej. W przypadku obrazów Adam i Ewa, Aniołowie u Abrahama, Walka Jakuba $z$ Aniołem oparto się na wcześniejszych badaniach zawartych w Dokumentacjach Budowy Technicznej autorstwa Ewy Mitury, Agaty Lubochońskiej oraz Eweliny Pawlak, powstałych w Zakładzie Technologii i Technik Malarskich pod kierunkiem: prof. dr art. kons. J. Flika, dr hab. J. Olszewskiej-Świetlik, mgr M. Górzyńskiej oraz badaniach specjalistycznych wykonanych w ramach pracy magisterskiej. Zastosowano metody instrumentalne do badań pigmentów i barwników: rentgenowska analiza fluoroscencyjna XRF przy zastosowaniu energodyspersyjnego spektrometru rentgenowskiego z układem helowym Mini Pal PW 4025, autor mgr A. Cupa w Zakładzie Technologii i Technik; neutronowa analiza aktywacyjna, autor mgr inż. E. Pańczyk, Instytut Chemii i Techniki Jądrowej w Warszawie; identyfikacja spoiw chromatografią gazową GC (większość próbek badano po rozkładzie $\mathrm{KOH}$, wybrane po $\mathrm{HCl}$ ), autor mgr G. Jaworski w Zakładzie Technologii i Technik Malarskich IZK, UMK. 
Wymiary płócien uzależnione były od prostokątnych pól w balustradzie empory. Krótsze boki obrazów mają długość około $87 \mathrm{~cm}$ natomiast dłuższe są zróżnicowane i wynoszą od 93 do $123 \mathrm{~cm}^{14}$. Płótna zostały wykorzystane zgodnie z kierunkiem wątku, a ich zapełnienie całkowite nie przekracza $70 \%$, użyto zatem płócien rzadkich ${ }^{15}$ Brak krajek, obecność zaprawy oraz okrągłych otworów i towarzyszącemu im ugięciu nitek na krawędziach płócien świadczy o korzystaniu w trakcie pracy z tzw. holenderskiego systemu naciągu. Napięte płótna przeklejono klejem glutynowym, który wniknął w wolne przestrzenie pomiędzy nitkami wątku i osnowy (il. 6). Na tak przygotowane podobrazia nałożono czerwoną zaprawę emulsyjną. Spoiwem zaprawy była emulsja o składzie: olej lniany, białko. Wypełniacz składał się z naturalnej czerwonej glinki żelazowej, czerni roślinnej i kredy. Średnia grubość zaprawy wynosi około $210 \mu \mathrm{m}$ (il. 7). Wiek XVII i XVIII to okres powszechnego stosowania barwnych zapraw w całej Europie ${ }^{16}$. Popularność gruntów barwnych, a przede wszystkim czerwonobrunatnych, wynikała $\mathrm{z}$ ich

14 Od wielkości warsztatów tkackich uzależnione były wymiary powstałej tkaniny. Na przykład warsztaty w Twente i Brabancji, stanowiące główne źródła zaopatrzenia w płótna dla północnej Holandii, produkowały tkaniny o szerokości wynoszącej ok. $138 \mathrm{~cm}$. Natomiast szerokość płócien włoskich wahała się od $106 \mathrm{do} 110 \mathrm{~cm}$; zob. J. Janson, Essential Vermeer Resoursec, http://www.essentialvermeer.com/technique/technique_support.html (8.05.2008).

15 E. Mirowska, M. Poksińska, B. Rouba, I. Wiśniewska, Identyfikacja podobrazi i spoiw malarskich w zabytkowych dziełach sztuki, Toruń 1992, s.158.

16 Por. m.in.: M. Koller, Das Staffeleibild der Neuzeit, w: Reclams Handbuch der Künstlerischen Techniken, Farbmittel, Buchmalerei, Tafel - und Leinwandmalerei, Bd 1 hrsg., H. Kühn, H. Roosen-Runge, R. E. Straub, M. Koller, Stuttgart 1988, s. 345-353; Wł. Ślesiński, Techniki malarskie. Spoiwa organiczne, Warszawa 1984, s. 139; J. Czernichowska, „Św. Stanisław Biskup wskrzeszający Piotrowina”. Obraz z kościoła w Drużbinie. Nietypowa budowa techniczna i technologiczna, "Ochrona Zabytków” 2002, nr 3-4, s. 300; eadem, Technika i technologia XVII-wiecznych obrazów przypisywanych Tomaszowi Dolabelli „Sw. Stanisław prowadzacy Piotrowina przed sąd królewski” $i$ „Gniew Boży” w kościele oo. Bernardynów w Warcie w świetle badań źródłowych, w: Ars Longa - Vita Brevis. Tradycyjne i nowoczesne metody badnia dzieł sztuki. Materiały z sesji poświęconej pamięci Profesora Zbigniewa Brochwicza, red. J. Flik, Toruń 2003, s. 199-200. Przykładem podobnych zapraw w siedemnastowiecznym malarstwie gdańskim są portrety Jana Heweliusza autorstwa Daniela Schulza, w których zastosowano czerwone zaprawy, por. J. Flik, Portrety Jana Heweliusza z Gdańska i Oxfordu - studium warsztatu malarskiego, „Ochrona Zabytków” 1995, nr 2, s. 169-170. 
właściwości optycznych. Barwa zaprawy wpływała na końcowy efekt kolorystyczny warstwy malarskiej ${ }^{17}$. Efekt ten był potęgowany również na skutek zmian chemicznych zachodzących w warstwach farb olejnych, które z czasem mogły stać się bardziej przezroczyste ${ }^{18}$.

Analizy w podczerwieni nie uwidoczniły rysunku kompozycji, co należy powiązać z ograniczeniem metody analitycznej przy obrazach wykonanych na ciemnych zaprawach lub zastosowanie przez warsztat malarski nietrwałego materiału rysunkowego, np. węgla drzewnego ${ }^{19}$. Kompozycje obrazów w dużej mierze pokrywają się z przytoczonymi wcześniej pierwowzorami graficznymi, co sugeruje korzystanie przez warsztat ze wzorników oraz powszechnych w owych czasach metod przenoszenia rysunku kompozycji ${ }^{20}$. Obrazy namalowano w technice wielowarstwowej. Do podmalowań stosowano spoiwo emulsyjne typu woda $\mathrm{w}$ oleju (olej lniany $\mathrm{z}$ niewielkim dodatkiem białka), do warstw wykończeniowych i laserunków spoiwo olejno-żywiczne. Głównym składnikiem spoiwa jest olej lniany. Paleta malarska składa się $\mathrm{z}$ następujących pigmentów: biel ołowiowa $\left(2 \mathrm{PbCO}_{3} \cdot \mathrm{Pb}(\mathrm{OH})_{2}\right)$ (il. 8), żółcień cynowo-ołowiowa, minia $\left(\mathrm{Pb}_{3} \mathrm{O}_{4}\right)$, cynober ( $\left.\mathrm{HgS}\right)$ (il. 9), indygo $\left(\mathrm{C}_{16} \mathrm{H}_{10} \mathrm{~N}_{2} \mathrm{O}_{2}\right)$ (il. 10), smalta $\left(\mathrm{CoO} \cdot \mathrm{nK}_{2} \mathrm{SiO}_{3}\right)$, azuryt naturalny $\left(2 \mathrm{CuCO}_{3} \cdot \mathrm{Cu}(\mathrm{OH})_{2}\right)$ (il. 11), malachit $\left(\mathrm{CuCO}_{3} \cdot \mathrm{Cu}(\mathrm{OH})_{2}\right)$, ziemia zielona

17 J. Janson, Essential Vermeer; Wł. Ślesiński, Techniki malarskie. Spoiwa organiczne, s. 139.

18 Wł. Ślesiński, Techniki malarskie. Spoiwa organiczne, s. 139.

19 Por. J. Flik, J. Olszewska-Świetlik, A. Cupa, A. Wypych, Rysunek w malarstwie sztalugowym. Badania metoda reflektografii w podczerwieni, w: Ksiega pamiatkowa ofiarowana profesorowi Wiesławowi Domasłowskiemu, red. B Soldenhoff, Toruń 2002, s. 49-56.

20 Posługiwanie się $\mathrm{w}$ trakcie pracy różnego rodzaju wzornikami wpisane było w tradycję warsztatową od najdawniejszych czasów. Wśród znanych w XVII wieku metod przenoszenia kompozycji ze wzornika na zaprawę można wymienić między innymi trzy stosowane najczęściej: przepróchę, vellum, czyli siatkę pomocniczą dzielącą kompozycję na kwadraty, kalkowanie przez transparentny papier. Pigmentami stosowanymi w tym procesie przy ciemnych zaprawach były zazwyczaj pigmenty jasne, np. biel ołowiowa, kreda i srebrny stylus. Por. J. Flik, J. Olszewska-Świetlik, A. Cupa, A. Wypych, Rysunek w malarstwie sztalugowym, s. 47-56; S. Wypchło, „Rysunek kompozycji w tablicowym malarstwie XV i początku XVI wieku. Sposoby identyfikacji”, praca magisterska pod kierunkiem dr hab. J. Olszewskiej-Świetlik, Zakład Technologii i Technik Malarskich UMK, Toruń 2005, mps, s. 13-20. 
(uwodnione glinokrzemiany: żelazowa, magnezowe i potasowe), czerń roślinna (ok. 95\% węgla, domieszki związków nieorganicznych wapniowych i potasowych) ${ }^{21}$.

Opracowanie malarskie rozpoczynano od szarego światłocieniowego podmalowania kompozycji. Proces przeprowadzono poprzez stopniowe rozjaśnianie na ciemnoczerwonej zaprawie warstwami jasnoszarej farby powstałej z utarcia bieli ołowiowej i czerni roślinnej z olejem lnianym. W partiach nieba podmalowanie modyfikowano dodatkami smalty lub cynobru z minią (il. 12). Modelowanie rozpoczęto od półtonów, pozostawiając najgłębsze cienie w kolorze zaprawy. Światła wzmacniano kolejnymi warstwami farby. Średnia grubość podmalowania w partiach półtonów wynosi ok. $28 \mu \mathrm{m}$, a świateł $70 \mu \mathrm{m}$. Dzięki nawarstwianiu farby w określonych miejscach uzyskano zmiany walorowe, które nadały podmalowaniu charakter płaskorzeźby. Tego typu światłocieniowe, monochromatyczne podmalowanie nosi nazwę en grisaille. Słowo pochodzi z języka francuskiego i oznacza „w szarościach”22. Modelunek szarością był jednym z elementów budowy technicznej XV-wiecznego malarstwa niderlandzkiego opisanego przez K. van Mandera pod nazwą "dootverwe"23.

Warstwy malarskie w kolorze lokalnym nanoszono na szare światłocieniowe podmalowanie od cieni do świateł. Kształtowanie elementów kompozycyjnych przeprowadzono podobnie jak i w warstwie podmalowania poprzez rozjaśnianie (il. 13). Grubość warstwy malarskiej w partiach cieni waha się od ok. 14 do $28 \mu \mathrm{m}$, natomiast w najwyższych świat-

21 P. Rudniewski, Pigmenty i ich identyfikacja, Warszawa 1995, s. 100; biel ołowiowa - s. 34, żółcień ołowiowa - s. 88, minia - s. 105, cynober - s. 103, indygo - s. 56, smalta - s. 58 , azuryt - s. 53, malachit - s. 69 , ziemia zielona - s. 73, czerń roślinna - s. 45.

22 K. Zwoliński, Z. Malicki, Mały słownik terminów plastycznych, Warszawa 1975, s. 61.

23 Szare ,grisaillowe” podmalowania występowały w wielu obrazach $\mathrm{z}$ tego czasu w Niderlandach, nazywane były „dootverwe”. Wykonywanie podmalowania było wymagane np. przez cechy, o czym świadczy \&10 ustawy korporacji malarskiej w Rouen. Zob. Z. Brochwicz, Toruński portret Kopernika w świetle nowych badań technologicznych, „Rocznik Muzeum w Toruniu” 1973, t. V, s. 120; J. Flik, Portret Mikołaja Kopernika $z$ Muzeum Okręgowego w Toruniu. Studium warsztatu malarskiego, Toruń 1990, s. 42. 
łach sięga w niektórych przypadkach ok. $70 \mu \mathrm{m}$. Sposób opracowania malarskiego, w którym grubość warstw pokrywających partie cieni jest cieńsza od grubości warstw półtonów i świateł, jest charakterystyczny dla XVII wieku, ze względu na modelowanie poprzez nakładanie warstw farby półkryjąco - tak, aby wykorzystać kolor podłoża ${ }^{24}$. Technika stanowi wypadkową zmian zachodzących $\mathrm{w}$ malarstwie sztalugowym związanym między innymi z zastosowaniem kolorowych zapraw i powszechnym wprowadzeniem spoiwa olejnego. Na podstawie przeprowadzonych badań stwierdzono, iż w trakcie pracy twórcy cyklu posługiwali się szeregiem zasad malarskich ułatwiających i przyspieszających malowanie. Podobny, pod względem użytych pigmentów skład farb, a także układ kolejnych warstw pozwala stwierdzić, iż podczas pracy nad wykonaniem obrazów posługiwano się przygotowanymi mieszaninami farb przeznaczonymi do określonych partii kompozycji. Praca w warsztacie malarskim odbywała się według określonych reguł wyznaczonych przez Mistrza. Czeladnicy zazwyczaj przygotowywali farby i nakładali je na paletę. Zdarzało się jednak tak, że sam Mistrz przygotowywał farby, by mieć pewność ich jakości. Zestaw kolorów używanych pigmentów uzależniony był od partii obrazu, którą zamierzano malować ${ }^{25}$. Obrazy namalowano przy określeniu zasad opisanych w traktatach malarskich. Wykorzystywanie starych, sprawdzonych receptur dotyczących przygotowania mieszanin pigmentów przeznaczonych do określonych partii malowidła jest jedną z cech malarstwa XVII wieku, mającą swe źródła $\mathrm{w}$ tradycji malarstwa warsztatowego. Wiele uwagi poświęcano zwłaszcza karnacjom. Przed przystąpieniem do malowania artysta miał przeważnie przygotowane trzy mieszaniny farb do opracowania modelunku w cieniu, półtonie i świetle ${ }^{26}$. Skład mieszanin był również uza-

24 M. Rzepińska podaje: „Zasada malowania cieni cienko i przejrzyście, a świateł »impasto «, jest zasadą odwrotną do praktykowanej przez mistrzów niderlandzkich w w. XV”. M. Rzepińska, Historia koloru w dziejach malarstwa europejskiego, Kraków 1983 , s. 319.

25 M. P. Merrifield, Medieval and Renaissance Treatises on the Arts of Painting: Original Texts With English Translations, Dover, New York 1999, s. 746; J. Janson, Essential Vermeer.

26 Ibidem, s. 314. 
leżniony od płci malowanej postaci, jej wieku oraz kondycji fizycznej ${ }^{27}$. Charakterystyczne dla badanych obrazów jest zwiększenie dodatku bieli ołowiowej jako pigmentu rozjaśniającego do partii półtonów i świateł ${ }^{28}$. Paleta malarska jest typowa dla tego czasu, niemal w całości pokrywa się z pigmentami powszechnie stosowanymi w XVII wieku, z wyjątkiem zieleni malachitowej i ziemi zielonej, których znaczenie w tym czasie znacznie osłabło. Analizy stężeń pierwiastków śladowych w bieli ołowiowej wykonane metodą neutronowej analizy aktywacyjnej (NAA) wykazały podobieństwa do szkoły gdańskiej oraz malarstwa niderlandzkiego. Biel różni się od szkoły małopolskiej i śląskiej (il. 8). Partie błękitnego nieba namalowano mieszaniną smalty z bielą ołowiową (il. 14). W partiach roślinności, by uzyskać efekt optycznego przybliżenia, zastosowano farbę złożoną z malachitu i czerni roślinnej, którą ocieplono dodatkiem innych pigmentów (zazwyczaj do tego celu stosowano żółcień cynowo-ołowiową). Efekt oddalenia uzyskano przez ochłodzenie farby dodatkiem smalty lub, jak w obrazach Adam i Ewa oraz Ofiara dziękczynna Noego, azurytu naturalnego. Stwierdzono również, że w warsztacie malarskim stosowano ziemię zieloną, którą zidentyfikowano w obrazie Ozeasz $i$ Gomer $z$ dziećmi. W wieku XVII paleta malarska składała się z podstawowych pigmentów, do których nie zaliczano pigmentów zielonych ${ }^{29}$. Natomiast w malarstwie gdańskim ograniczone użycie pigmentów zielonych widoczne jest już od początku XVI wieku ${ }^{30}$. Partie roślinności malowano mieszaninami pigmentów błękitnych i żółtych. Miało to uzasadnienie w zmianie upodobań i zasad określanych w traktatach malarskich tego czasu $^{31}$. Zastosowanie malachitu, choć nie jest charakterystyczne

27 Ibidem, s. 329.

28 Peter Paul Rubens, sztandarowy artysta baroku, zalecał malowanie cieni cienko, laserunkowo, a świateł farbą kryjącą z dodatkiem bieli (M. Rzepińska, Historia koloru $w$ dziejach malarstwa europejskiego, s. 319). Taki sposób traktowania warstwy malarskiej został zbadany w dwóch portretach Jana Heweliusza Daniela Schultza i Andreasa Stecha, artystów tworzących w Gdańsku w drugiej połowie XVII wieku. J. Flik, Portrety Jana Heweliusza $z$ Gdańska i Oxfordu - studium warsztatu malarskiego, s. 173.

29 M. Rzepińska, Historia koloru w dziejach malarstwa europejskiego, s. 314.

30 J. Olszewska-Świetlik, Technologia i technika malarska wybranych nowożytnych epitafiów z Bazyliki Mariackiej w Gdańsku, Toruń 2009, s. 44, 63,74, 103-105, $112,147-148$.

31 M.Rzepińska, Historiakoloruw dziejach malarstwaeuropejskiego, s.330-313. 
dla sztuki XVII wieku, może być efektem odmiennego podejścia do pigmentów zielonych, które obrazuje cytat Gerarda de Lairesse, żyjącego w latach 1640-1711, z traktatu pod tytułem Le Grand livre des peinters: „[...] godne pożałowania jest, że pewni malarze w ogóle wygnali zieleń ze swych krajobrazów i używają tylko czerni, ugrów i tym podobnych. Roślinność jest wszak zielona, a tu malarze stosują całe mnóstwo innych farb: niebieskich, żółtych rudych"32. Może również wynikać z popularności, jaką cieszył się ten pigment wśród artystów działających na terenie Polski, m.in. w Gdańsku ${ }^{33}$, w czasach wcześniejszych oraz ze stosunkowo niewielkiej odległości - w porównaniu z państwami zachodnimi - od kopalń malachitu znajdujących się na Uralu ${ }^{34}$. Pigmenty i inne materiały wykorzystywane przy wytwarzaniu farb malarze kupowali w wyspecjalizowanych sklepach, aptekach lub od marynarzy ${ }^{35}$. Choć już w połowie XVII wieku można było zakupić gotową farbę ${ }^{36}$, to jednak dopiero w połowie XIX wieku farby fabryczne weszły do powszechnego użycia $\mathrm{w}$ środowisku artystycznym ${ }^{37}$.

Faktura badanych obrazów w partiach świateł jest rozbudowana i urozmaicona, od łagodnych przejść w cieniach i półtonach namalowanych tzw. techniką ,"mokre w mokrym” przechodzi do warstw z wyraźnym duktem pędzla i wysokich impastów. Farby o gęstej konsystencji nanoszono szybkimi i pewnymi ruchami przy użyciu pędzli szczecinowych (il. 15). Fakturę wykorzystano świadomie do modelowania poszczególnych elementów kompozycji. Nanoszone precyzyjnymi a za-

32 Ibidem, s. 375. Traktat de Lairesse znajduje się w Bibliotece PAN w Gdańsku. G. de Lairesse, Groot schilderboek, waar in de schilderkonst in al haar deelen grondog werd onderweezen, ook door redeneeringen en printverbeeldingen verklaard, met voorbeelden uyt de beste konst-stukken der oude en nieuwe puyk-schilderen bevestigd, Amsterdam 1714.

33 Por. m.in. J. Olszewska-Świetlik, Technologia i technika gdańskiego malarstwa tablicowego drugiej połowy XV wieku, Toruń 2005, s. 229, 270.

34 R. Hutnik, E. Piątek, J. Wierski, M. Sachanbiński, Vademecum zbieracza kamieni szlachetnych i ozdobnych, Warszawa 1984, s. 174.

$35 \mathrm{Z}$ zachowanych ksiąg rachunkowych aptekarza z Delft wynika, że Jan Johannes Vermeer van Delft (1632-1675) zaciągnął u niego dług na zakup żółcieni cynowo-ołowiowej. Zob. J. Janson, Essential Vermeer.

36 Ibidem.

37 Encyklopedia Powszechna PWN, t. II, s. 321. 
razem zdecydowanymi ruchami kolejne warstwy rozjaśniające nadały właściwy charakter karnacjom, tkaninom oraz roślinności (il. 16-17). Impastowo nakładane najwyższe światła, działające niczym relief, dodatkowo podkreśliły cechy poszczególnych elementów kompozycji. W końcowym etapie modelowania podkreślono wybrane elementy, takie jak szczegóły twarzy cienkimi liniami w kolorze ciemnobrązowym.

Biorąc pod uwagę wszystkie wymienione wyżej aspekty, nie można oprzeć się wrażeniu szybkości, w jakiej powstawały kolejne obrazy. Być może był to efekt stosunkowo dużego zamówienia na dwadzieścia osiem malowideł lub obowiązującej zasady, iż obrazy przeznaczone do wnętrz kościelnych malowano z mniejszą dbałością o szczegóły, co wynikało z odległości, z jakiej były oglądane ${ }^{38}$. Zgodność z prawidłami obowiązującymi w malarstwie drugiej połowy XVII wieku, a także pewność i zdecydowanie, z jakimi kształtowano elementy kompozycyjne, znamionują doświadczenie i wprawę autora. Powyższe cechy oraz stosunkowo dobry stan zachowania obrazów, wynikający z odpowiedniego przygotowania poszczególnych warstw, pozwalają wyciągnąć wnioski, iż cykl obrazów emporowych powstał w warsztacie malarskim należącym do cechu malarzy gdańskich. Podkreśla to również pochodzenie dzieł z kościoła pod wezwaniem św. Jana w Gdańsku, w którym znajdują się także obrazy takich mistrzów jak Abraham van den Blocke (1572-1628) czy Izaak van den Blocke (?-1628). Jednakże nie ulega wątpliwości, że obrazy $\mathrm{z}$ empory różnią się poziomem artystycznym nie tylko od dzieł van den Blocków, ale przede wszystkim od innych współczesnych im prac takich mistrzów jak np. Daniel Schulz (1615-1683) czy Andreas Stech (16351697). W Gdańsku cech malarzy został zatwierdzony statutem Rady Miejskiej 28 września 1612 roku. Członkami cechu byli zarówno artyści malarze, jak i zwykli rzemieślnicy. W Gdańsku działały liczne lokalne warsztaty malarskie, przybywali również artyści z kraju i zagranicy ${ }^{39}$.

38 A. Kozieł, Po co artysta rysuje? Kilka uwag na temat funkcji rysunku w twórczości Michaela Willmanna, „Sztuka i Kultura” 2001, nr 2; Disegno - rysunek u źródeł sztuki nowożytnej, red. T. J. Żuchowski, S. Dudzik, Toruń 2001, s. 216.

39 Gdańsk był ośrodkiem, w którym działali liczni artyści rodzimi i obcy. Por. m.in. T. Grzybowska, Złoty wiek malarstwa gdańskiego na tle kultury artystycznej miasta. 1520-1620, Warszawa 1990, s. 47.W literaturze znajdujemy stwierdzenia, że prośbę o założenie cechu malarskiego w 1592 roku podpisało 28 malarzy; zob. A. Gosieniecka, 
W związku z powyższym obrazy powstałe w tym okresie w Gdańsku prezentują zróżnicowany poziom artystyczny. Przeprowadzone badania technologii i techniki malarskiej obrazów emporowych z kościoła pw. św. Jana w Gdańsku wykazały, że powstały one w jednym z cechowych lokalnych warsztatów. Ewidentne różnice w poziomie artystycznym zauważalne w obrazach świadczą o tym, że zostały namalowane przez kilka osób co było typowe dla dzieł powstających w dużej pracowni malarskiej. W warsztacie tym posługiwano się szeregiem zasad charakterystycznych dla malarstwa XVII wieku (wykorzystanie podobrazi płóciennych, stosowanie spoiwa olejnego, ciemnoczerwonych zapraw), a także zbiorem zasad wynikających z tradycji cechowej kultywowanej od wcześniejszych stuleci: korzystanie z wzorników graficznych przy tworzeniu kompozycji, posługiwanie się określonymi mieszaninami farb do opracowań poszczególnych partii kompozycji obrazów, stosowanie szarego podmalowania oraz techniki wielowarstwowego modelunku malarskiego. Podsumowując, można stwierdzić, że obrazy emporowe z kościoła pw. św. Jana w Gdańsku, zarówno pod względem treści, jak i warsztatu malarskiego, wpisują się w zasady cechowego malarstwa drugiej połowy XVII wieku szkoły północnej.

Sztuka w Gdańsku. Malarstwo, rzeźba, grafika, w: Gdańsk: jego dzieje i kultura, red. F. Mamuszka, Warszawa 1969, s. 298. Natomiast już ok. 1600 roku w Gdańsku działało 60 artystów; zob. za J. Tylicki, Rysunek gdański ostatniej ćwierci XVI i pierwszej połowy XVII wieku, Toruń 2005, s. 15; zob. również: A. Mosingiewicz, Effigies ante omnia. Jacob Wessel i malarstwo portretowe $w$ Gdańsku XVII wieku, w: Portret ponad wszystko. Jacob Wessel i jego wiek. Sztuka Gdańska XVIII wieku. Katalog wystawy w Muzeum Narodowym $w$ Gdańsku 15.12.2005-26.02.2006, red. A. Mosingiewicz, D. Kaczor, Gdańsk 2005, s. 33; J. Pałubicki, Malarze gdańscy, t. I-II. 


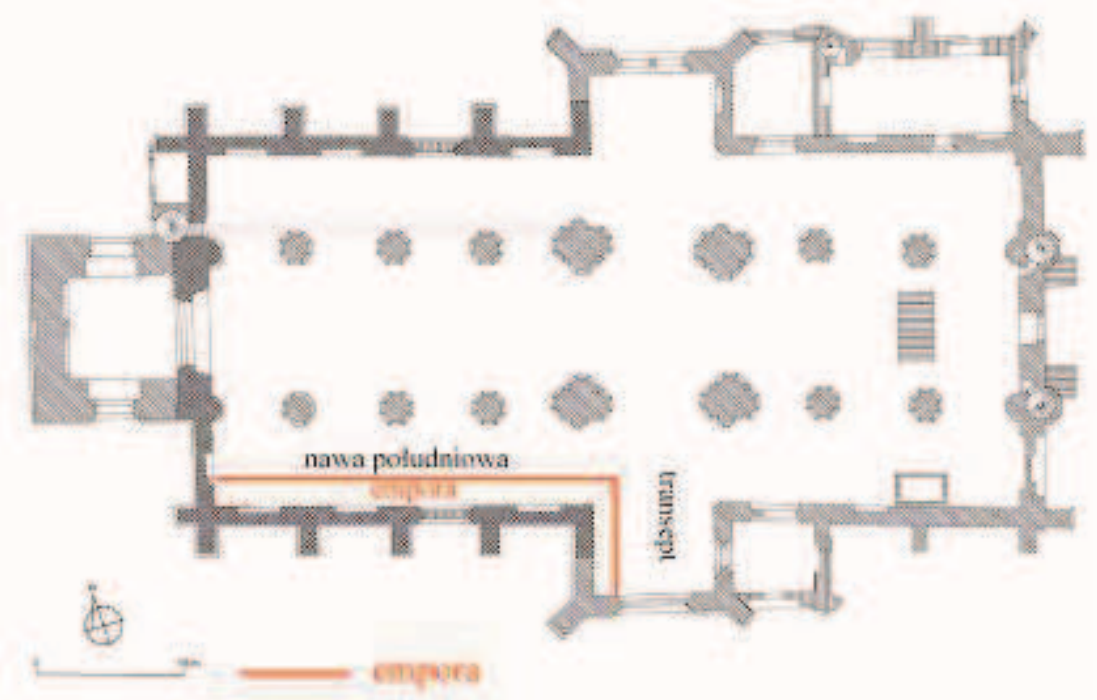

Il. 1. Rzut kościoła pw. św. Jana w Gdańsku z naniesieniem położenia empory, aut. P. Matuszewski, Muzeum Archeologiczne w Gdańsku, http://www.archeologia.pl/ index.php?n=7\&m=4\&p=12 (19.10.2009)

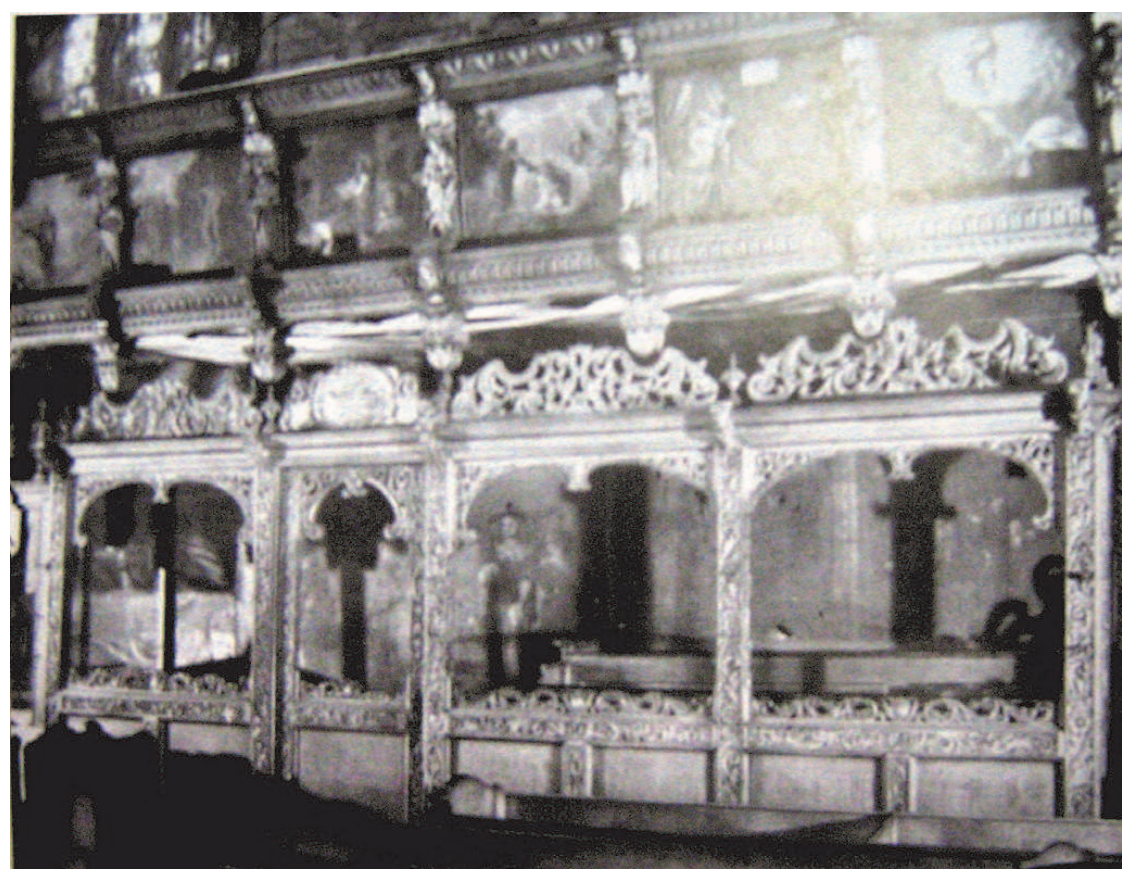

Il. 2. Empora $\mathrm{w}$ nawie południowej (fot. P. Haustain, P. Gronert, w: W. Drost, Künstdenkmäler der Stadt Danzig-Sankt Johann, Stuttgart 1957, s. 88) 


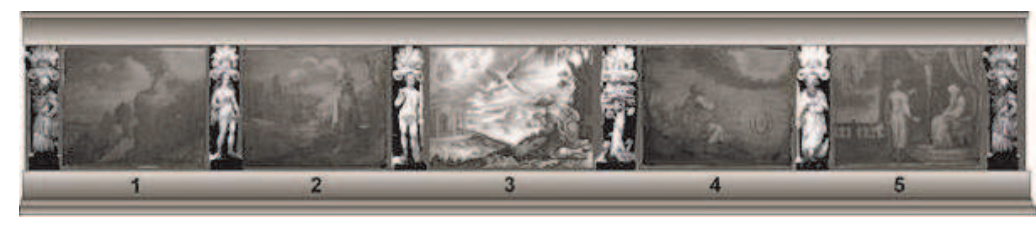

a)

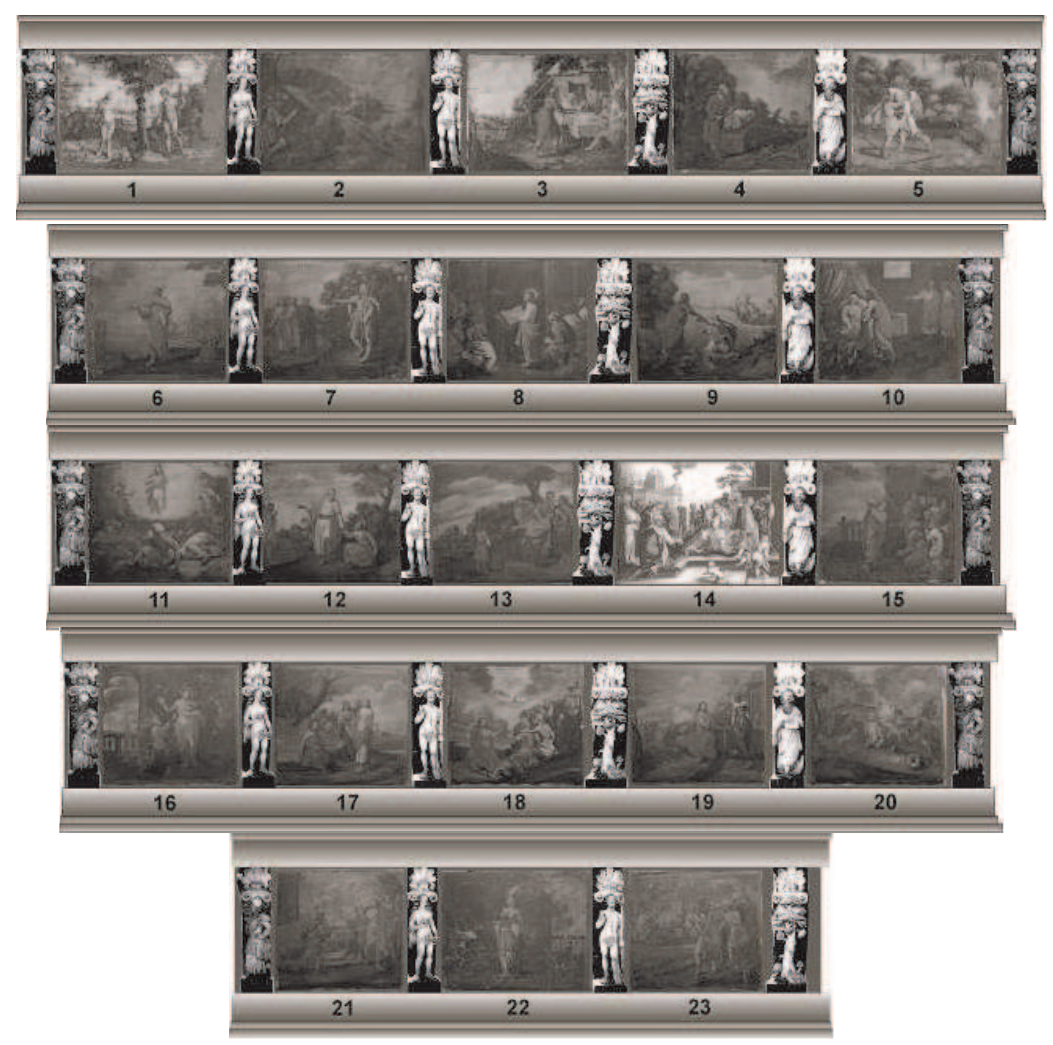

b)

Il. 3. Rekonstrukcja empory (aut. E. Pawlak)

Il. 3a. Rekonstrukcja empory z transeptu (wyróżniono obrazy poddane badaniom): 1. Adam i Ewa, 2. Ofiara dziękczynna Noego, 3. Aniołowie u Abrahama, 4. Ofiarowanie Izaaka, 5. Walka Jakuba z Aniołem

Il. 3b. Rekonstrukcja empory z nawy południowej (wyróżniono obrazy poddane badaniom): 1. Mojżesz na górze Synaj, 2. Prorok Jeremiasz z jarzmem na szyi, 3. Oczyszczenie warg Izajasza (zaginął), 4. Wizja kół ognistych Ezechiela, 5. Daniel tlumaczy sen Nabuchodonozora, 6. Ozeaszi Gomer zdziećmi, 7. Św. Jan Chrzciciel, 8. Chrystus i uczeni w piśmie, 9. Chrystus ratujący tonącego św. Piotra, 10. Wskrzeszenie córki Jaira, 11. Przemienienie Pańskie, 12. Powołanie św. Filipa, 13. Cudowne rozmnożenie chleba, 14. Chrystus błogosławiący dzieci (zaginął), 15. Zesłanie Ducha Świętego, 16. Chrystus ukazujący się niewiernemu Tomaszowi, 17. Uzdrowienie niewidomego, 18. Chrystus nauczajacy, 19. Chrystus $z$ Samarytanka przy studni, 20. Nawrócenie św. Pawła, 21. Powołanie św. Mateusza, 22. Córka Herodiady Salome z głowa św. Jana Chrzciciela, 23. Chrystus ukazujący się dwóm uczniom $w$ drodze do Emaus 


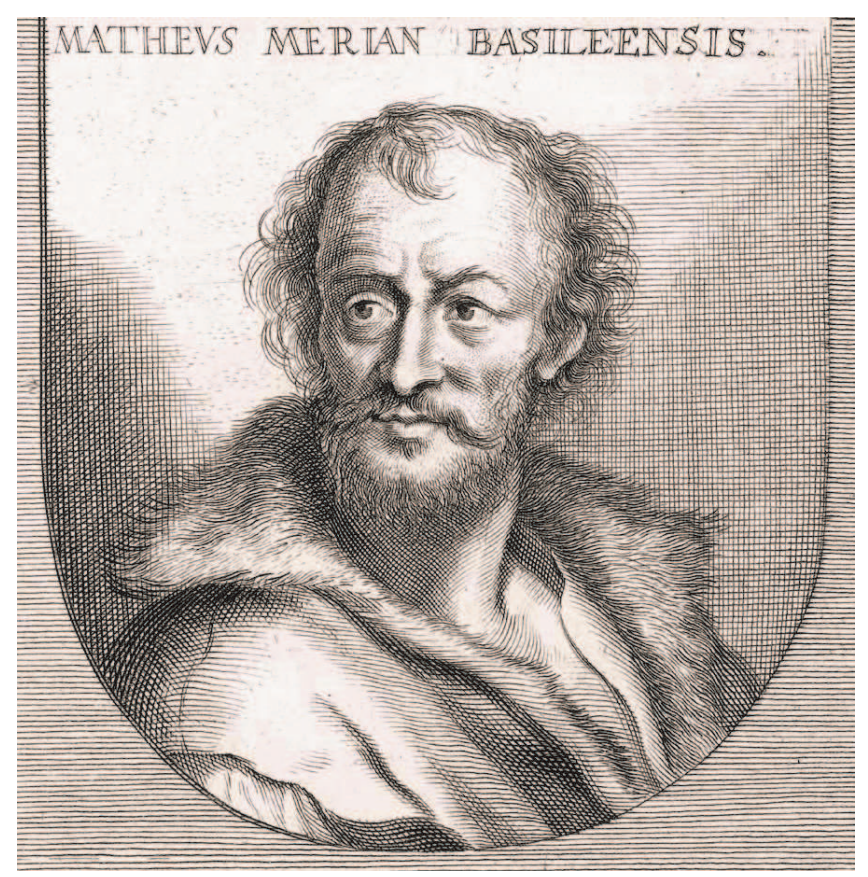

Il. 4. Portret Mateusza Meriana St., http:// de.wikipedia.org/w/index.php?title=Datei: MatthaeusMerian.jpg\&filetimestamp $=200$ $50728011236(24.03 .2009)$

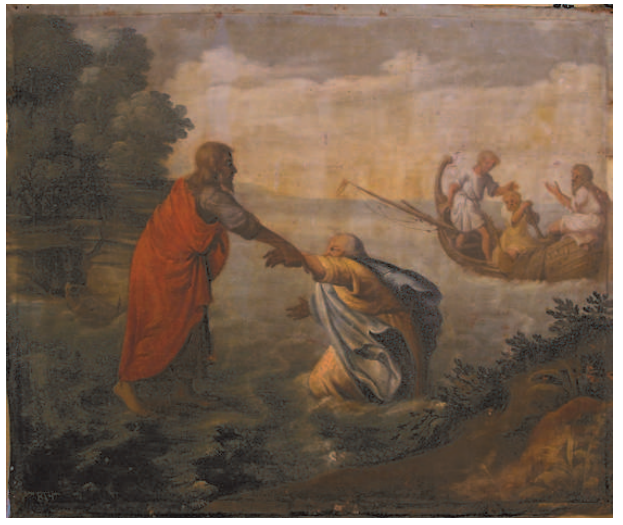

Il. 5a. Obraz Chrystus ratujacy św. Piotra z empory kościoła pw. św. Jana w Gdańsku (fot. E. Pawlak)

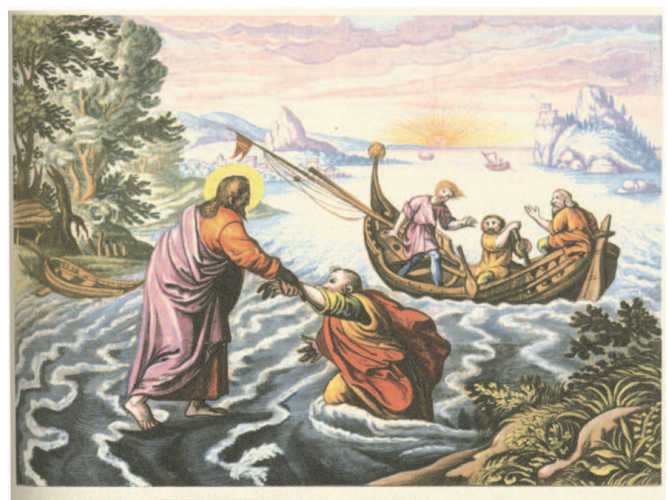

JESUS WANDELT AUF DEM MEER Matthäus 14,22-33

Il. 5b. Grafika M. Meriana St. pochodząca z Die Merian Bibel (Stuttgart 1980, s. 1159) 


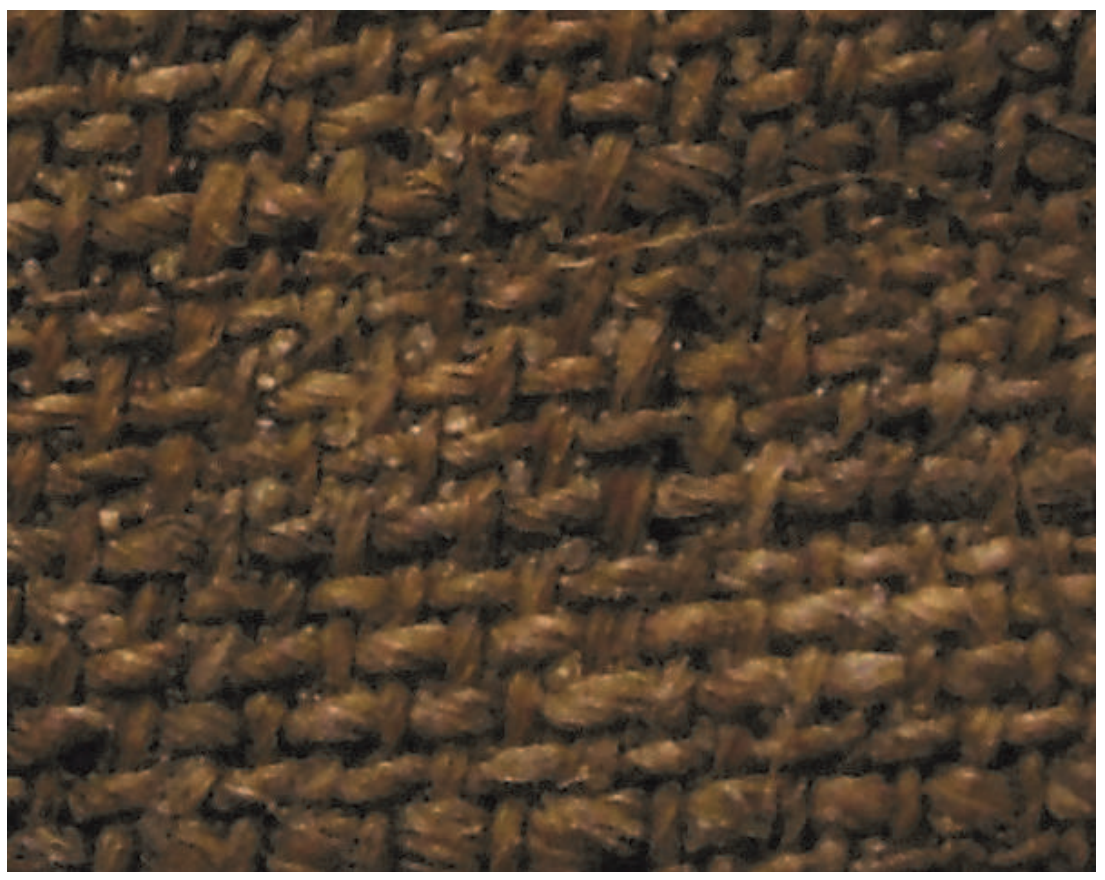

Il. 6. Zbliżenie podobrazi, odwrocie. Płótno lniane o rzadkim zapełnieniu wątkiem i osnową, splot prosty, $\mathrm{z}$ widocznym pomiędzy nitkami przeklejeniem, wykonanym klejem glutynowym (fot. E. Pawlak)

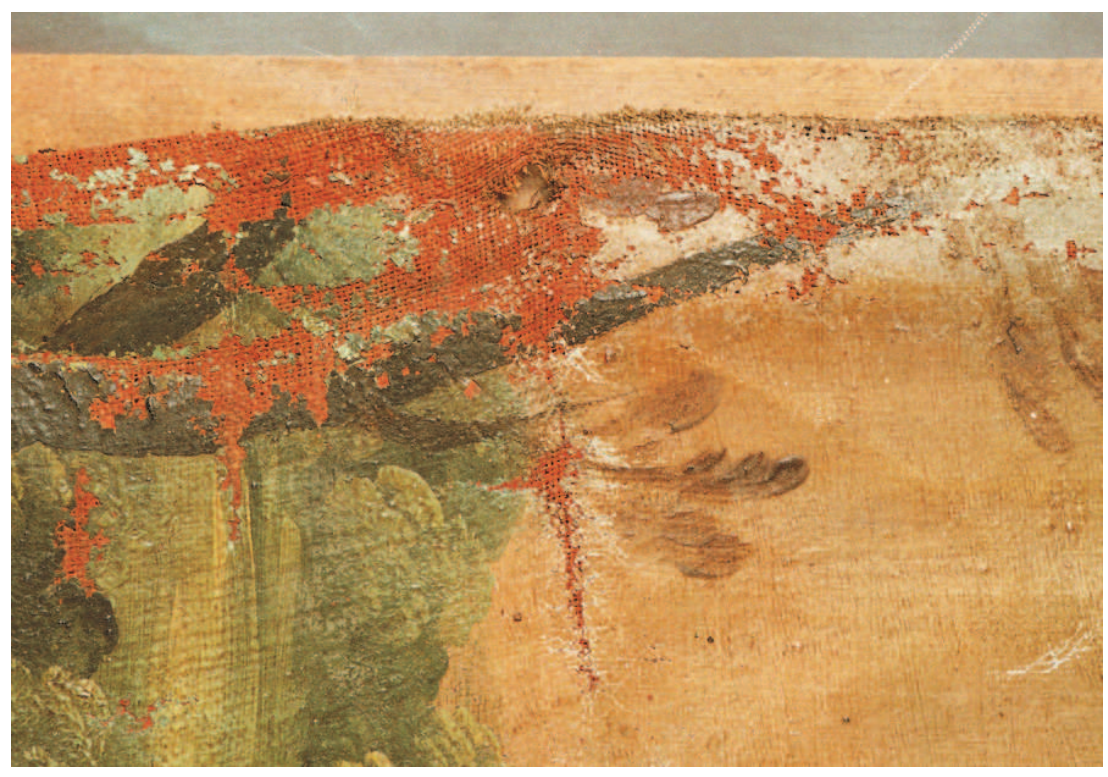

Il. 7. Fragment obrazu Aniołowie u Abrahama, ubytki warstwy malarskiej odsłoniły czerwoną zaprawę emulsyjną (fot. E. Pawlak) 


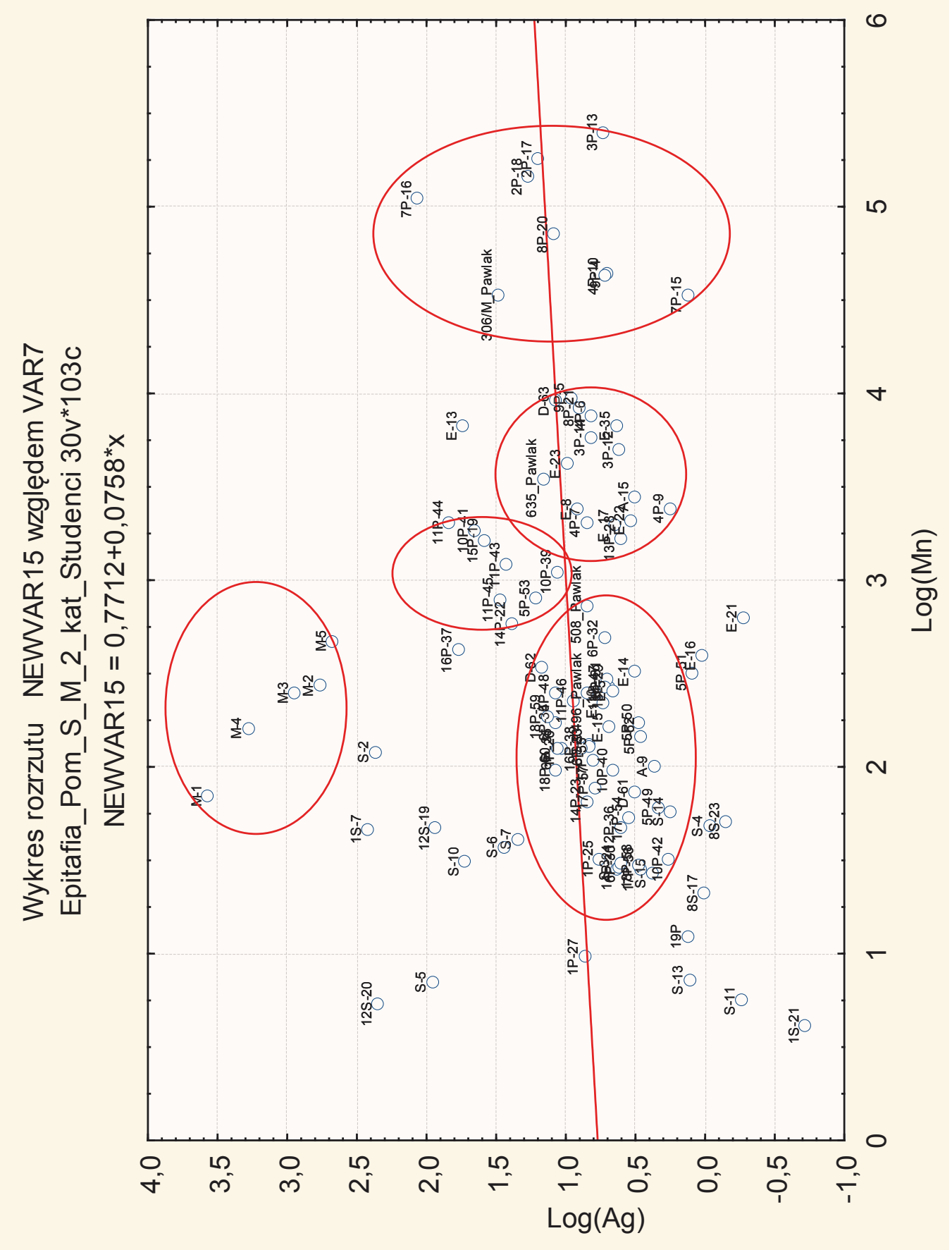




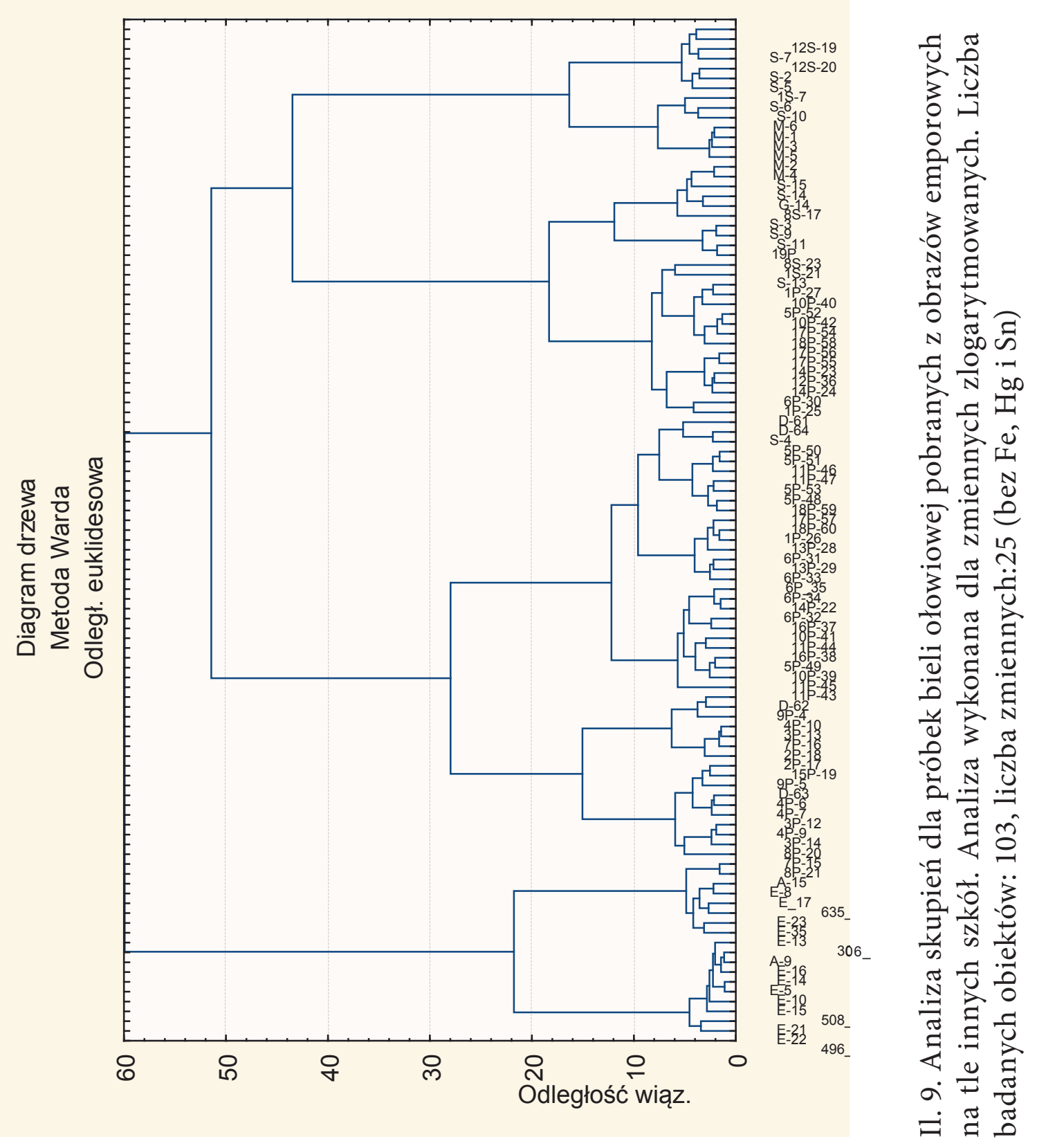


Spis badanych próbek (biel ołowiowa). Epitafia gdańskie, szkoła pomorska, małopolska, śląska, niderlandzka, niemiecka XV i początek XVI wieku, obrazy emporowe XVII wiek

(wyk. E. Pańczyk, J. Olszewska-Świetlik)

\section{Szkoła pomorska}

1P-25 $\div 29$ Retabulum Maryjne bractwa kapłańskiego, Bazylika Mariacka, Gdańsk 1473-1478

2P-17 $\div 18$ Predella ze scenami męczeństwa św. Adriana,

Bazylika Mariacka, Gdańsk po 1468

3P-12 $\div 14$ tzw. Duży ołtarz Ferberów, Bazylika Mariacka,

Gdańsk 1480-1498

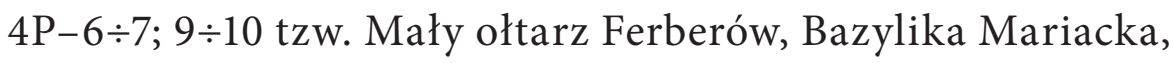

Gdańsk 1485-1490

5P-48 $\div 53$ Tryptyk Jerozolimski, Bazylika Mariacka,

Gdańsk 1490-1500

6P-30 $\div 35$ Tryptyk z Ukrzyżowaniem, Bazylika Mariacka,

Gdańsk 1480-1500

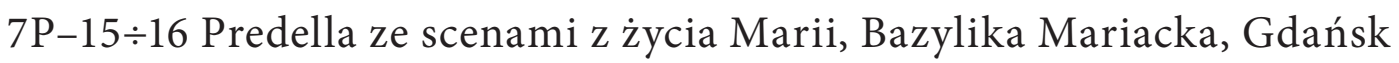

$1485-1490$

8 P-20 $\div 21$ Tablica 10 Przykazań, Bazylika Mariacka,

Gdańsk 1480-1490

9P-4 $\div 5$ Obraz Chrystus Zbawiciel na drzwiczkach tabernakulum, Bazylika Mariacka, Gdańsk 1478-1482

10P-39 $\div 42$ Retabulum św. św. Szymona i Judy Tadeusza, Bazylika Mariacka, Gdańsk 1485-1490

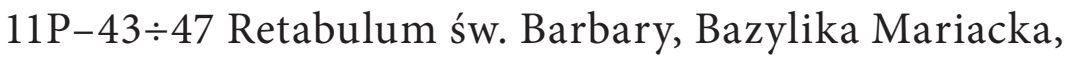

Gdańsk 1480-1500

12P-36 Obraz wotywny Ukazanie Chrystusa, Bazylika Mariacka, Gdańsk

$1483-1500$

13P-28, 29 Predella Biczowanie, Cierniem Koronowanie,

Bazylika Mariacka, Gdańsk po 1487

14P-22 $\div 24$ Predella Maria $z$ Dzieciątkiem, Bazylika Mariacka,

Gdańsk po 1478

15P-19 Predella Koronacja Marii, Bazylika Mariacka,

Gdańsk 2 poł. XV w. 
16P-37, 38 Predella Chrystus i 12 Apostołów, Bazylika Mariacka, Gdańsk ok. 1500

17P-54 $\div 58$ Skrzydła ołtarza przedstawiające sceny z życia Marii, retabulum z kaplicy we Wróblewie ok. 1500

18 P-59 $\div 60$ Skrzydła ołtarza z kościoła św. św. Piotra i Pawła w Helu ok. 1500

19P Poliptyk grudziądzki, kaplica zamku krzyżackiego ok. 1390

E-13 Portret Christofa von Suchten, Muzeum Narodowe w Gdańsku 1507

\section{Szkoła małopolska}

M-1 Adoracja Chrystusa (Opłakiwanie), Chomranice 1438-1439

M-2 Tryptyk Matka Boska Bolesna, Kamionka Mała 1456

M-3 Święta Katarzyna Aleksandryjska, kwatera z retabulum w Bieczu 1470

M-4 Opłakiwanie z Czarnego Potoku 1449

M-5 Tryptyk z Nowego Sącza 1452

M-6 Tryptyk z Ptaszkowej 1440

\section{Szkoła śląska}

S1-7, 21 Tryptyk Ukrzyżowanie, kościół parafialny,

Gać Śląska 1440-1450

S-2 Ołtarz św. Barbary, kościół św. Barbary, Wrocław 1447

S-3 Veraikon wrocławski, kościół św. Barbary, Wrocław 1460

[129]

S-4 Veraikon legnicki, kościół NP Marii w Legnicy 1450

S-5 Tryptyk Ukrzyżowanie fundacji Petera Wartenberga, katedra we Wrocławiu 1468

S-6 Epitafium Mikołaja Werdera, kościół św. Barbary, Wrocław 1456

S-7 Tryptyk z Legendą św. Jadwigi, kościół Bernardynów, Wrocław 1440

S8-17 Matka Boska z Dzieciątkiem, klasztor wrocławskich klarysek, Wrocław 1460

S8-23 Kwatera ze scenami z życia św. Jakuba, Wrocław 1460

S-9 Madonna $w$ komnacie, pochodzenie nieznane 1460-1465

S-10 Poliptyk Życie Chrystusa i Marii, kościół pw. św. Elżbiety we Wrocławiu 1482 
S-11 Epitafium Andrzeja Steinberga, kościół św. św. Stanisława i Wacława w Świdnicy 1486/1487

S-12 - 19,20 Retabulum, kościół pw. św. św. Piotra i Pawła w Strzegomiu 1486/1487

S-13 Obraz wotywny Chrystus Bolesny Ofiarowany przez Boga Ojca, kościół pw. św. Elżbiety we Wrocławiu 1486/1487

S-14 Epitafium Księcia Wacława Żagańskiego, kościół pw. św. Barbary we Wrocławiu 1486/1487

S-15 Retabulum, kościół Panny Marii na Piasku we Wrocławiu 1486/1487

\section{Szkoła niemiecka i niderlandzka}

G-14 Hans Pleydenwurff - retabulum, kościół św. Elżbiety we Wrocławiu 1462

D - 61 $\div 64$ Hans Memling - Tryptyk Sad Ostateczny,

Bazylika Mariacka 1473

Ołtarz antwerpski, Bazylika Mariacka, Gdańsk

A-15 Złożenie do Grobu 1510

A-9 Umywanie Rack 1510

Szkoła gdańska (epitafia) - Bazylika Mariacka, Gdańsk

1E-8 Epitafium Johanna Connerta 1554/1556

2E-10 Epitafium Michaela Loitza 1561/1564

2E-15 Epitafium Michaela Loitza 1561/1564

2E-14 Epitafium Michaela Loitza 1561/1564

2E-17 Epitafium Michaela Loitza 1561/1564

2E-5 Epitafium Michaela Loitza 1561/1564

3E-16 Epitafium Georga Hojera 1586

4E-21 Epitafium Jacoba Schadiusa 1588

5E-22 Epitafium Hansa Gronau 1612

5E-13 Epitafium Hansa Gronau 1612

5E-35 Epitafium Hansa Gronau 1612

Malarstwo emporowe z kościoła pw. św. Jana w Gdańsku ok. 1666

306_Pawlak Chrystus i uczeni w piśmie (nawa południowa)

496_Pawlak Ofiara dziękczynna Noego (transept)

508_Pawlak Wskrzeszenie córki Jaira (nawa południowa)

635_Pawlak Zesłanie Ducha Świętego (nawa południowa) 

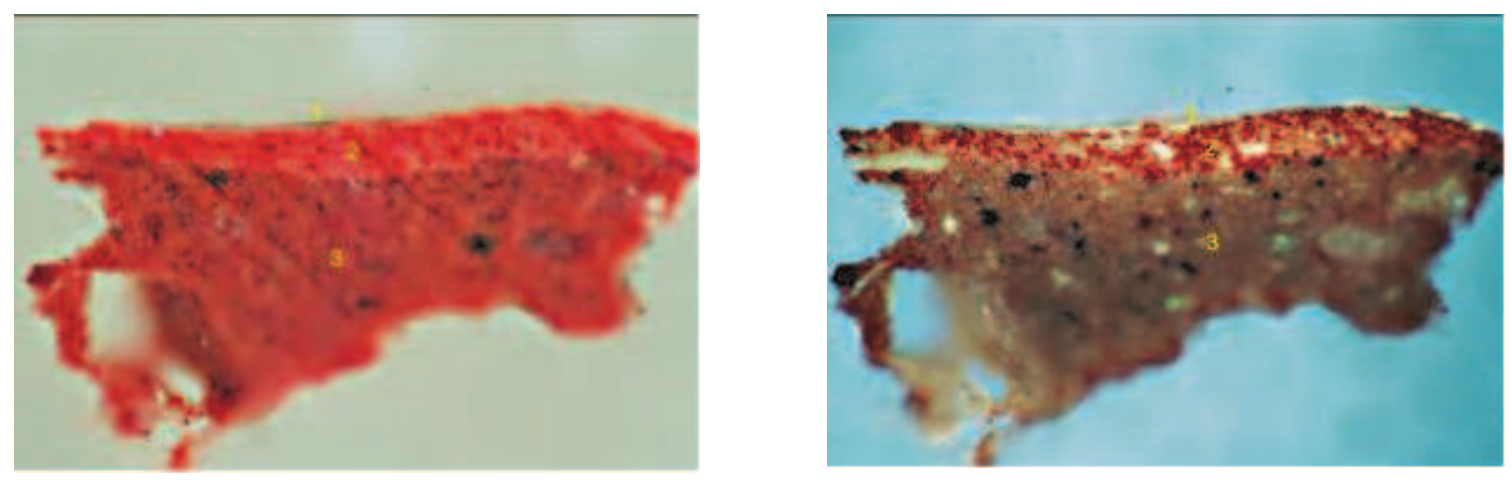

Il. 10a-b. Chrystus i uczeni w piśmie, przekrój próbki czerwonej szaty, zestawienie fotografii mikroskopowej w świetle VIS i UV (fot. Z. Rozłucka)

1 - werniks; 2 - warstwa czerwona: cynober, minia (w UV charakterystyczne czerwone cząstki cynobru i intensywne świecenie minii); 3 - czerwona zaprawa: naturalna czerwona glinka żelazowa, czerń roślinna, kreda (osłabienie luminescencji w UV przez czerwoną glinkę żelazową i czerń roślinną)
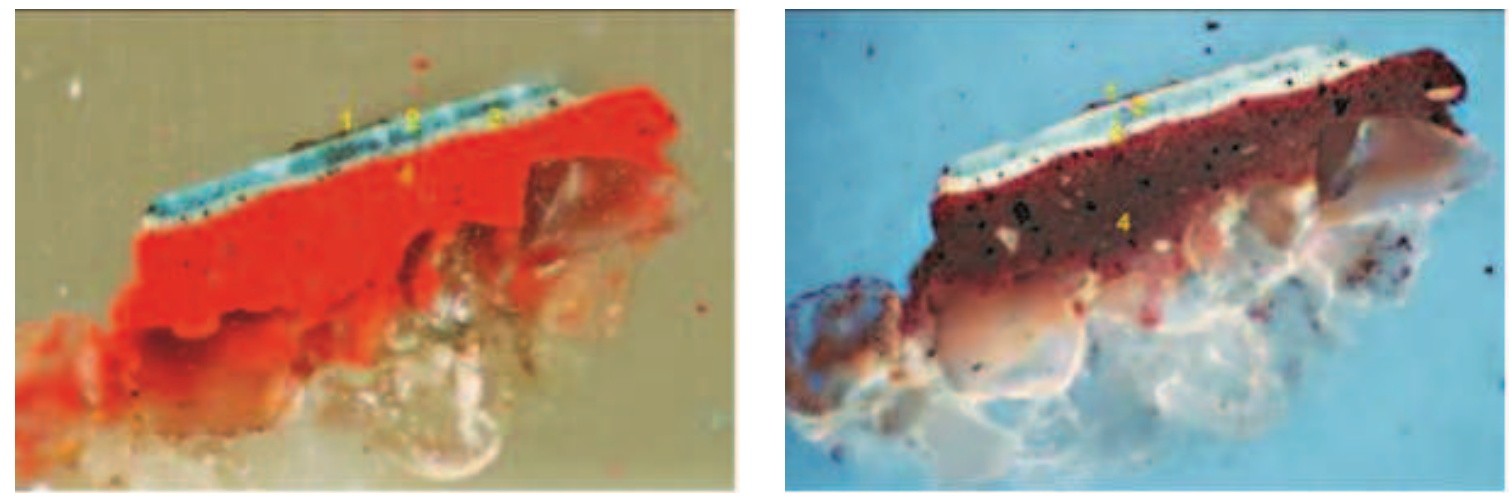

Il. 11a-b. Chrystus i uczeni w piśmie, przekrój próbki błękitnej szaty, zestawienie fotografii mikroskopowej w świetle VIS i UV (fot. Z. Rozłucka) 1- werniks; 2 - błękitna warstwa malarska: biel ołowiowa, błękit organicznyindygo, (w UV świecenie cząsteczek bieli ołowiowej i jasnoniebieska fluorescencja charakterystyczna dla indyga); 3 - szare podmalowanie: biel ołowiowa, czerń roślinna (w UV intensywne świecenie bieli ołowiowej); 4 - czerwona zaprawa: naturalna czerwona glinka żelazowa, czerń roślinna, kreda (osłabienie luminescencji w UV przez czerwoną glinkę żelazową i czerń roślinną) 

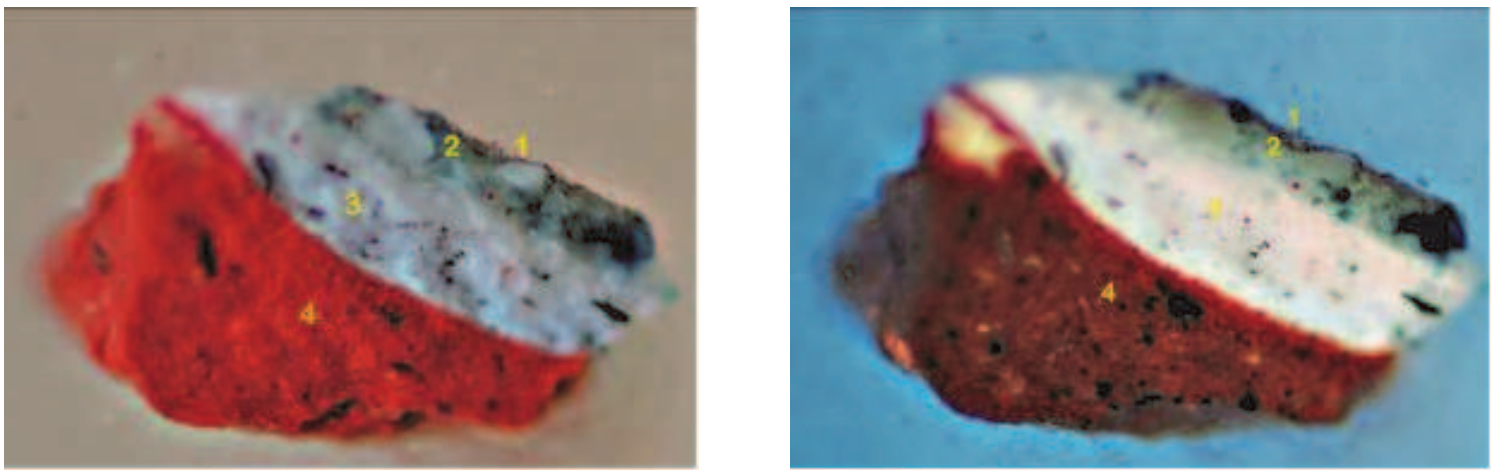

Il. 12a-b. Ofiara dziękczynna Noego, przekrój próbki zieleń z drzew, zestawienie fotografii mikroskopowej w świetle VIS i UV (fot. Z. Rozłucka) 1 - werniks; 2 - warstwa zielona: azuryt naturalny, biel ołowiowa (wygaszanie luminescencji przez pigment miedziowy w UV); 3 - szare podmalowanie: biel ołowiowa, czerń roślinna (intensywne świecenie bieli ołowiowej w UV); 4 - czerwona zaprawa: naturalna czerwona glinka żelazowa, czerń roślinna, kreda (osłabienie luminescencji w UV przez czerwoną glinkę żelazową i czerń roślinną)

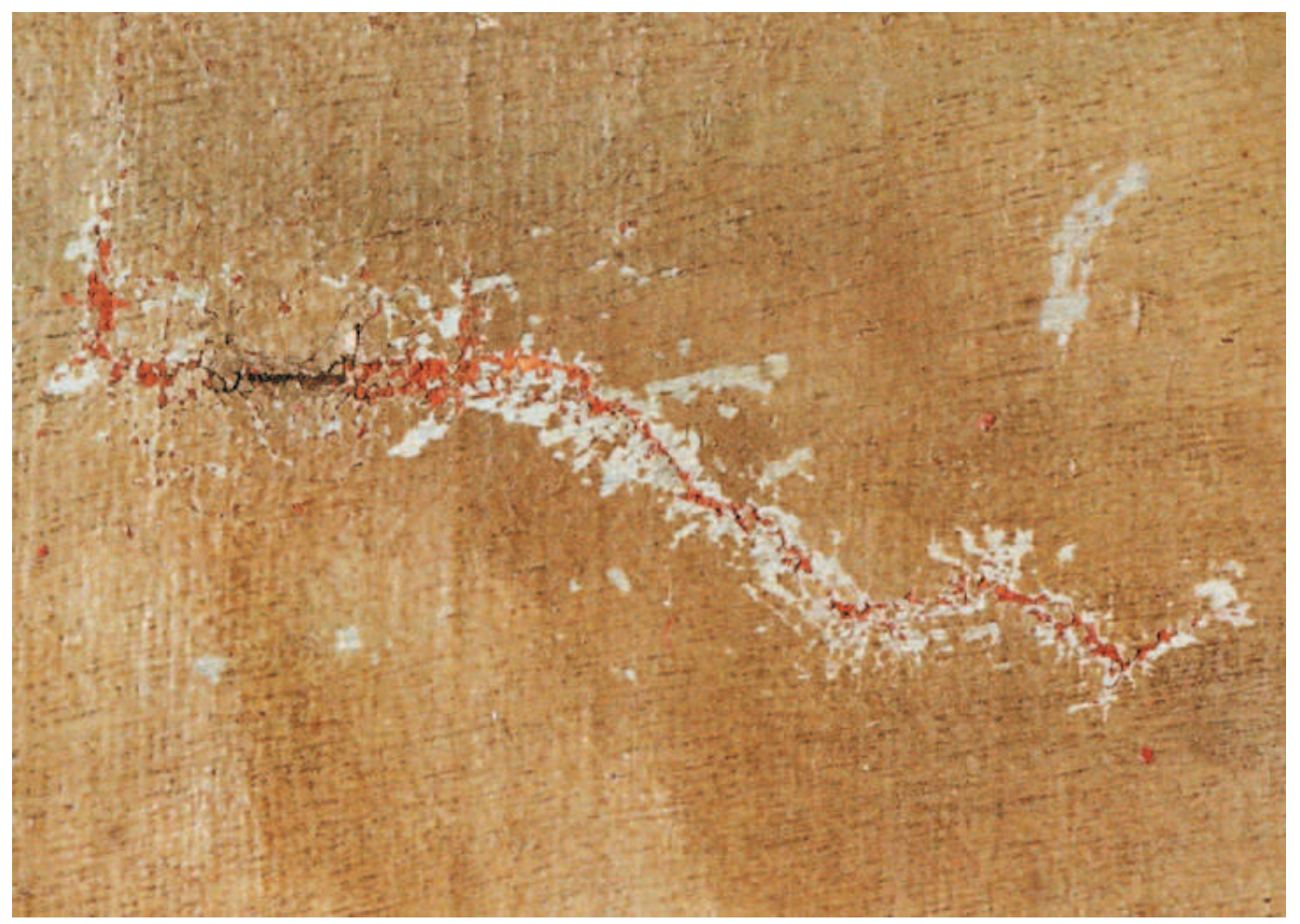

Il. 13. Fragment partii chmur $\mathrm{z}$ widocznym w ubytkach podmalowaniem (fot. E. Pawlak) 


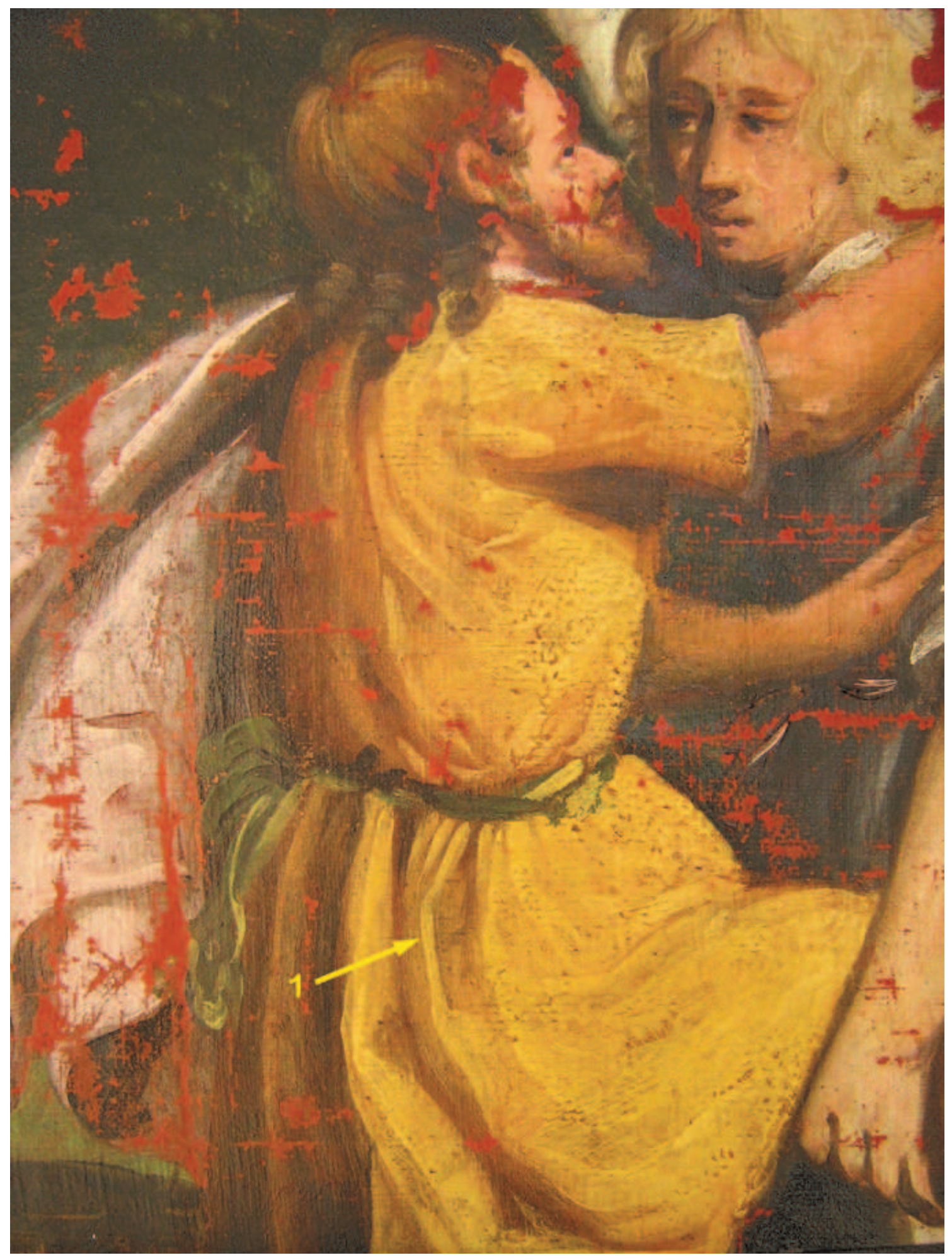

Il. 14. Fragment obrazu Walka Jakuba $z$ Aniołem, widoczny sposób malowania szaty od cieni do świateł; 1 - szybkie pociągnięcia pędzla modelujące fałdy i załamania tkaniny (fot. E. Pawlak) 

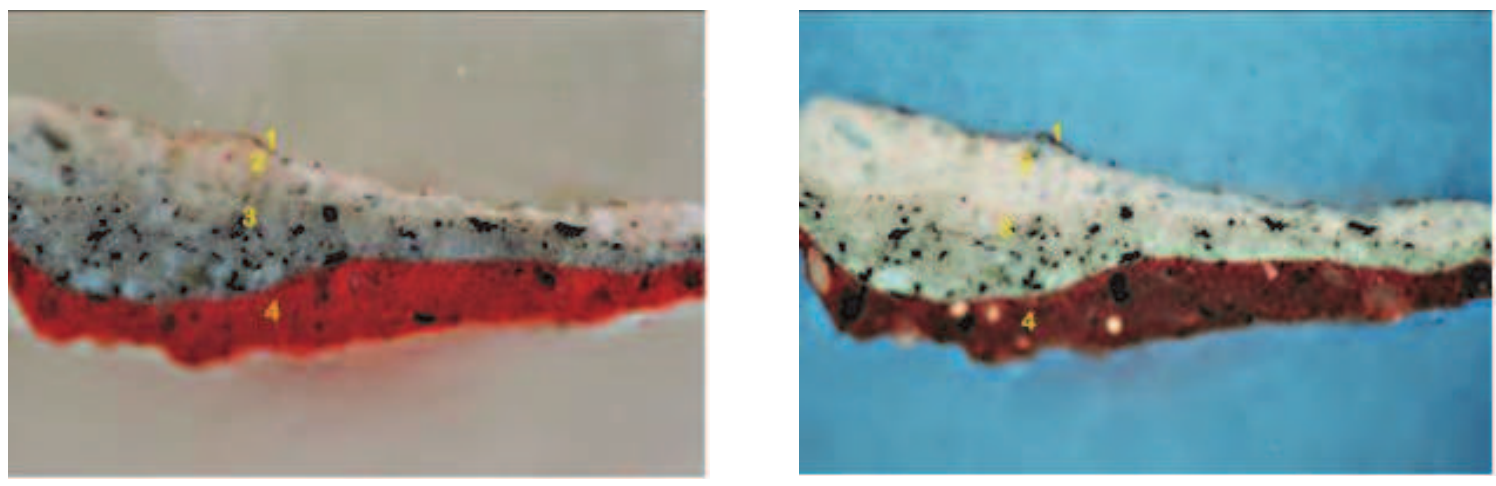

Il. 15a-b. Ozeasz i Gomer z dziećmi, przekrój próbki z błękitu, niebo, zestawienie fotografii mikroskopowej w świetle VIS i UV (fot. Z. Rozłucka)

1 - werniks; 2 - warstwa jasnobłękitna: biel ołowiowa, smalta (w UV intensywne świecenie bieli ołowiowej oraz uwidoczniony charakterystyczny kształt ostrokrawędzistych ziaren smalty); 3 - szare podmalowanie) biel ołowiowa, czerń roślinna (w UV intensywne świecenie bieli ołowiowej i wygaszenie luminescencji przez czerń roślinną); 4 - czerwona zaprawa: naturalna czerwona glinka żelazowa, czerń roślinna, kreda (osłabienie luminescencji w UV przez czerwoną glinkę żelazową i czerń roślinną)

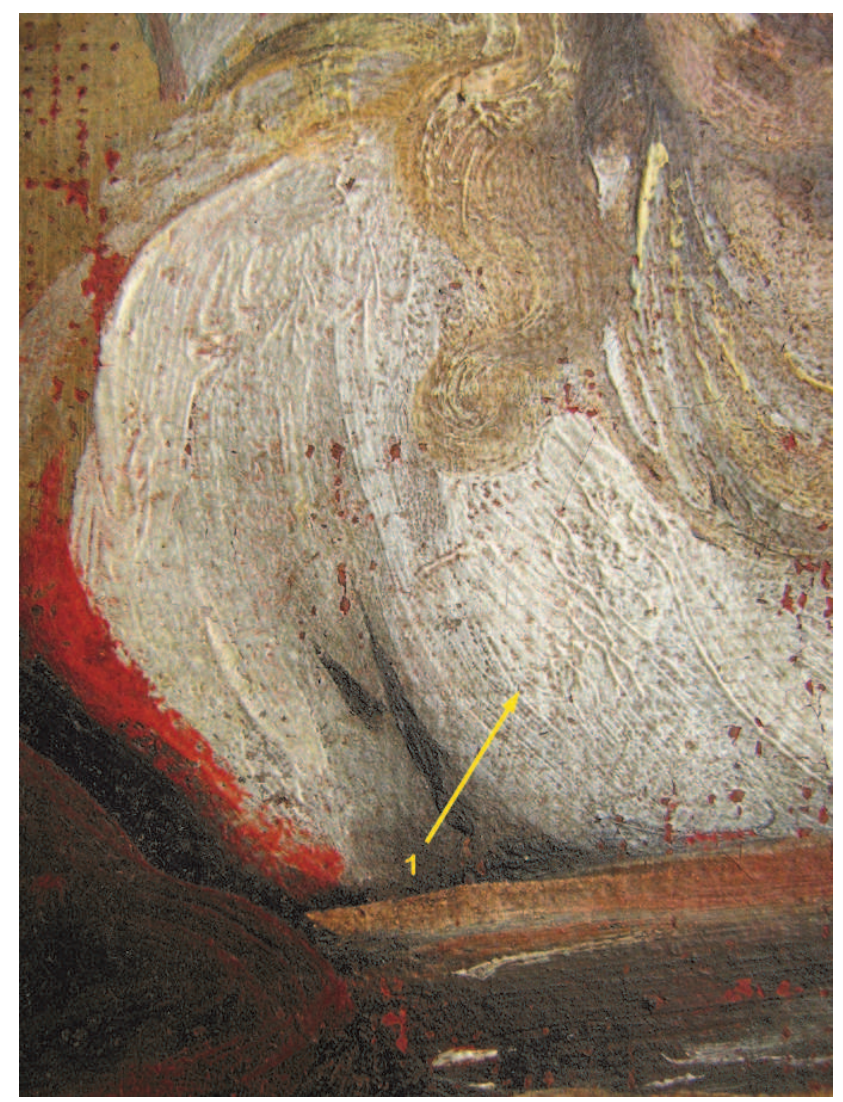

Il. 16. Aniołowie u Abrahama, zbliżenie białej szaty anioła, 1 - wyraźna faktura powstała w wyniku nakładania warstwy farby pędzlem szczecinowym (fot. E. Pawlak) 


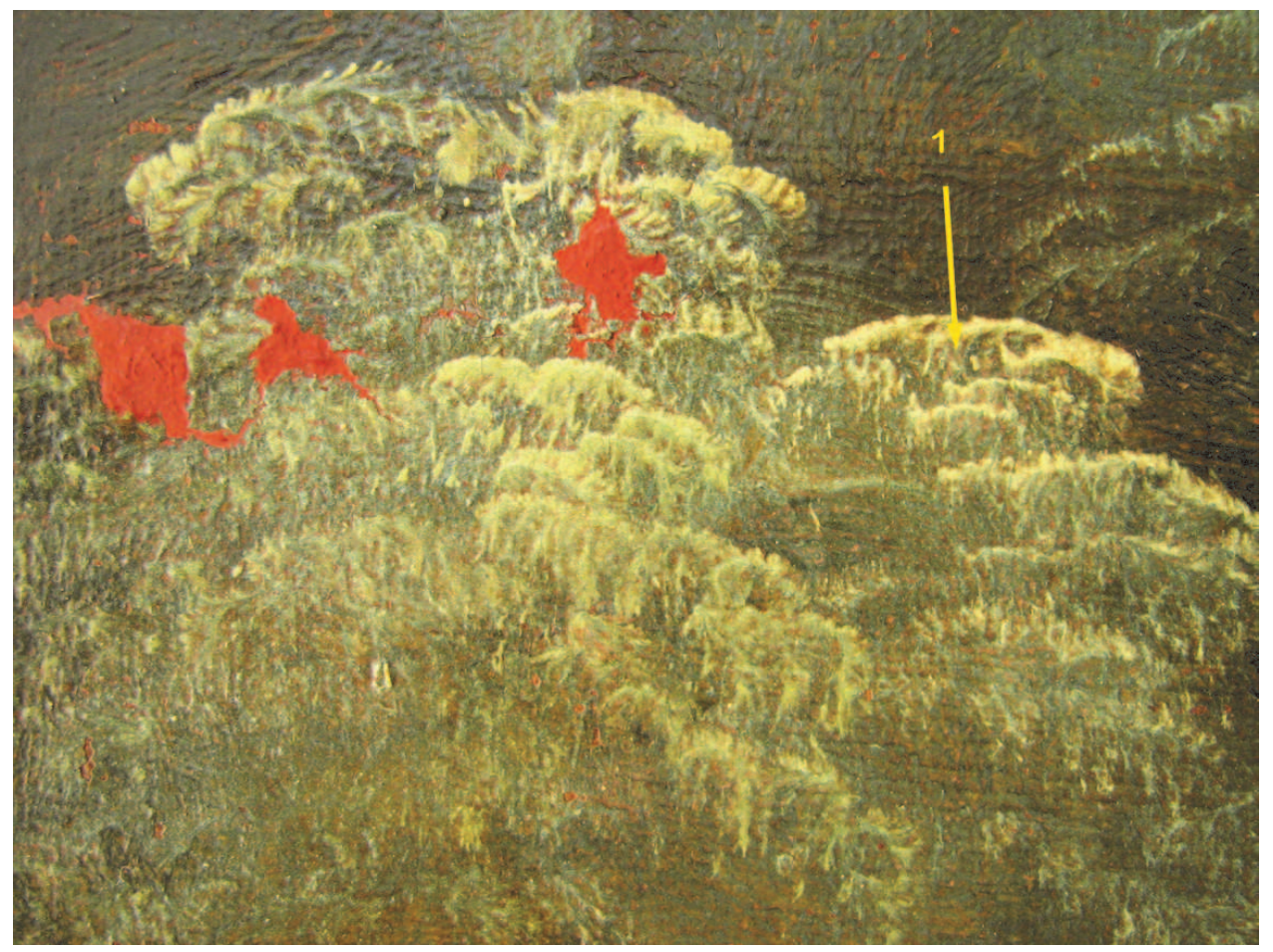

Il. 17. Walka Jakuba z Aniołem, zbliżenie liści drzew, 1 - charakterystyczny sposób formowania korony drzew (fot. E. Pawlak)

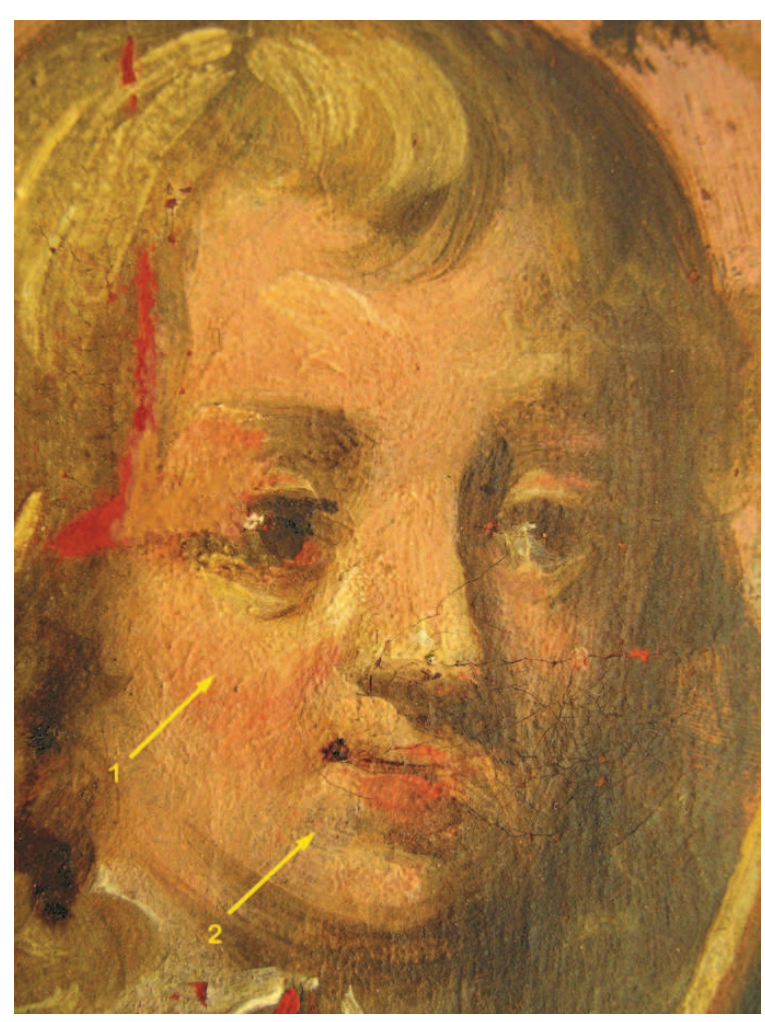

Il. 18. Aniołowie u Abrahama, zbliżenie twarzy anioła, 1 - widoczny wyraźny dukt pędzla szczecinowego; 2 - prześwitywanie warstwy szarego podmalowania przez cienkie warstwy półtonów. Linearnie brązem podkreślono kształt nosa, oczu i podbródka (fot. E. Pawlak) 


\section{Summary}

\section{The painting techniques used in the cycle of the choir gallery pictures from St John's Church in Gdańsk}

The article presents issues concerning the techniques used by the painting workshop commissioned to make a cycle of paintings (dating 1666) which decorate the choir gallery in St John's Church in Gdańsk. The technical specification of the paintings as well as the identification of the painting materials were carried out by means of mutually supplementary modern physical methods, including microscopic, chemical and instrumental examinations. The analyses of the technology and painting techniques of the paintings in question show that they came from a local guild workshop. The evident differences in the artistic level indicate that the paintings were made by several craftsmen, which was typical of big painting workshops of the time. The workshop used a variety of techniques characteristic of $17^{\text {th }}$ - century painting, such as the use of linen painting basis, oil binder, dark red priming ground, as well as the use of formers in the process of creating a paining. (In this particular case, the inspiration came from the drawings by Matthew Meriana the Older, to be found in a Lutheran Bible printed in Strasburg in 1630 by the printing house of Lazarus Zetzner.) The workshop used special mixtures of paints for individual parts of a painting, together with grey underpainting layer and multi-layer modelling. It has been found that, with respect to both the content and the painting techniques, the choir gallery paintings from St John's Church in Gdańsk manifest features typical of the guild painting of the northern school of the second half of the seventeenth century. 